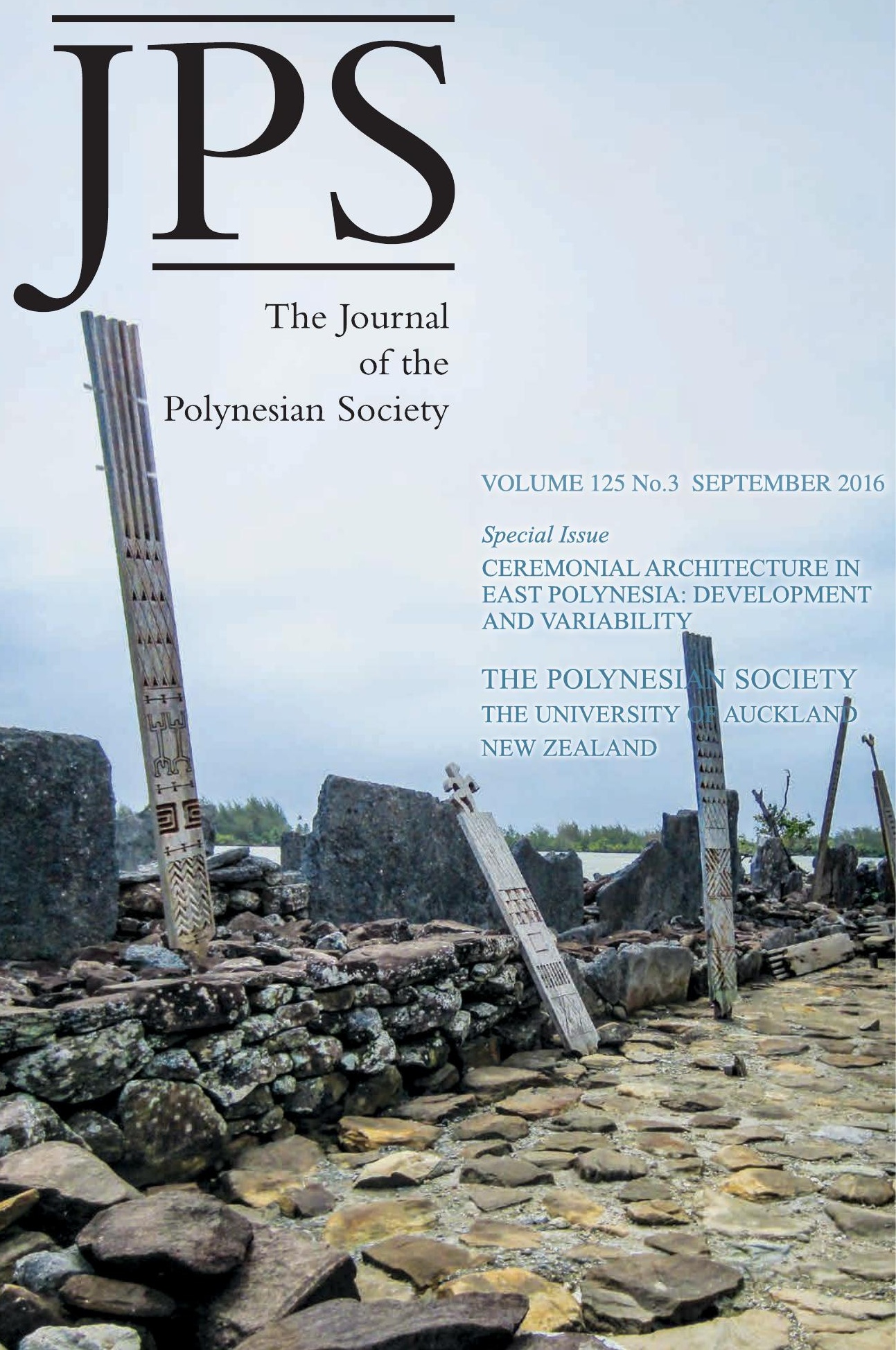




\title{
THE FUNCTIONALITY OF FEASTING AT LATE PREHISTORIC RESIDENTIAL AND CEREMONIAL SITES IN THE SOCIETY ISLANDS
}

\author{
JENNIFER G. KAHN \\ College of William and Mary
}

Much of the research into East Polynesian ceremonial sites focuses on marae$a h u$ 'temple-altar' complexes as sacred sites where varied religious rituals and rites of passage were performed. Yet ethnohistoric documents and the Tahitian lexicon suggest a broader role for Ma'ohi or 'indigenous Tahitian' ceremonial architecture, specifically as the foci of individual and corporate ceremonies of a religious, economic and political nature. Situating ceremonial marae complexes within broader archaeological landscapes likewise speaks to the integrated socio-political and ritual nature of Society Islands ceremonial architecture. This case study investigates the role of feasting on terraces attached to Ma'ohi marae complexes and within communal spaces found in residential complexes. Utilising a spatio-temporal perspective, I investigate the function of feasting at a range of community and familial level temples and residential complexes found in the 'Opunohu Valley, an inland valley context on Mo'orea Island (Windward Society Islands). My goal is to explore the ways that Ma'ohi household leaders, chiefs and priests may have utilised feasting to materialise their economic or political authority, while at the same time facilitating the formation of communal identities. A second goal is to identify whether the specific function of feasting differed at monumental architectural sites of varying scale and complexity, utilising both archaeological evidence and ethnographic analogy. Finally, a third goal is to investigate change through time in the scale and intensity of feasting at specific locales, in particular, whether community level or corporate feasting intensified and became a strategy used by socio-religious elites to formalise and extend social alliances.

\section{BACKGROUND TO FEASTING STUDIES IN MIDDLE RANGE SOCIETIES AND POLYNESIAN CHIEFDOMS}

Feasts include the communal consumption of food or drink (Dietler and Hayden 2001); they are typically both qualitatively and quantitatively different from everyday domestic meals in the types and amounts of foods and drink that are served. Feasts can be forms of ritual activity, in that they link power displays with social action (oratory, drinking, dancing) and thus can become the stage for other transformative social acts such as gift 
exchange. They are also inherently political events (Dietler 2001) where status is negotiated, alliances and marriage exchanges are created, and conflict is resolved.

Studies have delineated varied types of feasting with diverse goals, including work party feasts, solidarity feasts, solicitation feasts, tribute feasts and maturation and life event feasts, among others (Dietler 2001, Hayden 2001). The form and function of these specific types of feasting, as well as their scale and intensity of occurrence through time (Chicoine 2011, Potter 2000), have been recent topics of investigation. Feasting events can empower different social groups at different social scales (Reinhart 2015). At the community scale, feasting events are central to hierarchical reproduction, as they bring together and express a wide range of social relations. There is growing realisation that feasting, as a highly visible event of some import, can be an agent of social transformation, in structuring the social relations of production, in creating new identities, in enlarging the prestige of leaders, and in constructing political alliances (Emerson 2008, Hayden 2001, 2014, Knudsen et al. 2012, Reinhart 2015).

In middle range societies, societies that are intermediate in terms of political complexity like chiefdoms, feasting serves as a highly visible social act, representing not only a local or political leader's generosity, but delineating boundaries of particular social groups and their control over resources. In effect, feasting nourishes the status of a group, but it often has simultaneous functions and effects. Feasts can be highly integrative while at the same time exclusive, joining elite leaders with commoners by highlighting their shared kinship ties and integrating households at the local level, while at the same time showcasing socio-economic, ritual or political power of local and regional leaders and their differential status visà-vis the rest of the populace (Knudsen et al. 2012, Potter 2000). Hayden's (2014) recent comparative synthesis argues that feasting is underlain by three general motives: social bonding, material and economic benefits, and status distinction, supporting the event's often multi-faceted character as a simultaneous social, economic and political act.

In the past, public feasting events involving the community were financed at the supra-household level (Potter 2000) and were sometimes held in specialised communal spaces, typically on or near sacred sites (temples, monuments, tombs, ancestor shrines) or other types of specialised locales (men's houses) and sometimes in structures having specialised facilities (Blitz 1993, Chicoine 2011, Hayden 2014). Such feasts were often regulated by ceremonial participation in the ritual calendar. In contrast, residential feasting commonly took place at, or adjacent to, specific house sites or within communal places and ritual zones in household complexes (Junker 
and Niziolek 2010, Nash 2010) and were financed at the household level (Potter 2000). Thus, the spatial context of feasting as well as its scale and intensity can provide clues to the type of feast offered as well as its goals, whether to promote within group or between group solidarity, to aggrandise and gain prestige, to broaden social networks and alliances, or to create debt.

In Polynesia, feasting is not well documented archaeologically, but is well known from historic sources. Ethnographic analyses characterise Polynesian feasts quantitatively as involving supra-households groups and large amounts of food per consumer, and qualitatively as having high numbers of ritually marked foods or delicacies (Kirch 2001; see also Oliver 1989: 291-92). Polynesian scholars differentiate household level or domestic feasting versus community level feasting, and sacred versus secular versus political feasting (Kirch 2001: 171, Table 6.2; see also Kirch 1991: 131, Oliver 1974: 231, 259-64, Thomas 1990: 89-97). Much research has focused on the ways in which political elites in Polynesian chiefdoms utilised feasts as sources of socio-ritual and political power (Kirch 2001, Kolb 1994, 1999, 2006, Thomas 1990). Leach's (2003) survey of East Polynesian ethnohistoric records documents widespread traditions of hospitality, including food sharing, status display through feasting and elaborate social rules governing public feasts. Both sacred and secular community-wide feasts hosted by district chiefs or paramount chiefs indebted neighbouring chiefs who were invited to attend, and materially displayed the socio-economic and political power of particular leaders through lavish spectacles of food, ceremony, feasting and dance. Such feasts took place in spatially defined places that were marked by permanent, and often elaborate, stone structures, including temples (marae, me 'ae, heiau) and other structures (dance grounds [tohua], council platforms). Some elite feasts were highly exclusive, permitting only a few individuals of similarly high status and high political rank to participate in order to emphasise alliance linkages. Similarly, ceremonies marking different stages of an elite's life (rites of passage) or political career broadcasted the ideological underpinnings of their socio-ritual and economic power to the rest of the populace, as did sacred ceremonies embedded into the ritual calendar, where large amounts of foodstuffs and prestige items were funnelled up to the elites from the general populace in the form of tribute.

While much has been made of elite feasting in Polynesia, in most regions ethnographic data illustrate the importance of feasting within and between commoner households as well as among and between elite households (Goldman 1970: 500-5). Residential feasts at the local level established and perpetuated social relationships, while at the same time excluding different groups (Kahn 2005, Kirch 2001; see also Dietler 2001: 88-90, Hayden 2001: 29-30). 


\section{ETHNOHISTORIC AND ETHNOGRAPHIC DATA FOR FEASTING IN THE SOCIETY ISLANDS}

Ethnographic and ethnohistoric data, as well as glosses from the first Tahitian dictionary (Davies 1851) illustrate that the major types of Society Island feasts included residential and secular events, residential and ritualised events, communal and secular events, and communal and ritualised events that were typically also political in nature (Table 1). Community-wide feasts often had a strongly exclusive nature. While they brought the entire community together at the temple, often to present tribute items, only the most sacred elites could actively take part in these public rituals. The less sacred or profane (commoners, women) participated only indirectly from the "outside", as members of the audience watching those actively involved in the rituals taking place within the sacred precincts of the marae enclosure. In contrast to these community scale events, commoners and women could actively participate in local level residential rituals and feasts. Thus, social class played an important part in dictating the host of Society Island feasts as well as the audience of the feast and their appropriate levels of participation.

\section{Household Feasts}

Ethnohistoric and ethnographic data for the Society Islands indicate the importance of the household and household groups as the basic unit of production (Oliver 1974). Ma'ohi households worked land held in common and participated in domestic ritual and feasting at their familial or ancestral marae (Henry 1928: 141). The activities of household groups had widespread importance in marking social difference and establishing and maintaining social relations. In house societies such as the Society Islands, the practice of daily activities, such as shared preparation and consumption of foodstuffs, served as markers of house affiliation while at the same time emphasising the boundary of the house to others (Kahn 2007).

Glosses for Ma'ohi household level feasts (Table 1) highlight how these events often focused on life stages of children, such as cutting of the umbilical cord or removing food tapu 'taboo'. It is likely that both high status and low status households staged such events, either at their familial temples or at communal spaces within residential complexes. Life stage domestic feasting served dual purposes - to re-establish and strengthen kinship bonds - but also to increase perceived status at the local level, both to participants of the feast and the surrounding community. The ethnohistoric evidence implies that staple goods and non-staple goods held equal importance in smaller family feasts and gift exchange (Henry 1928: 128-29, 198, Morrison 1935: 347). 
Jennifer G. Kahn 207

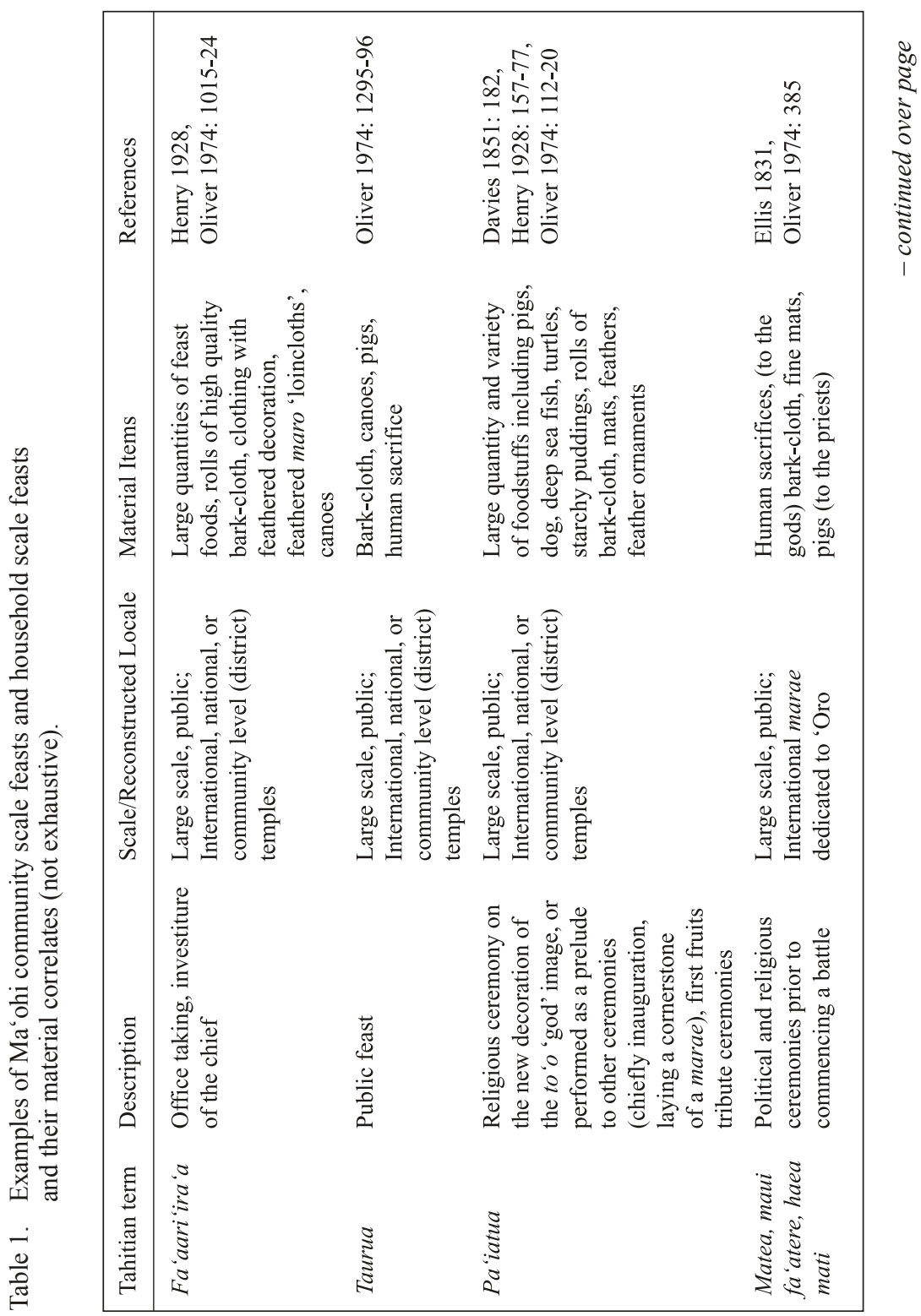




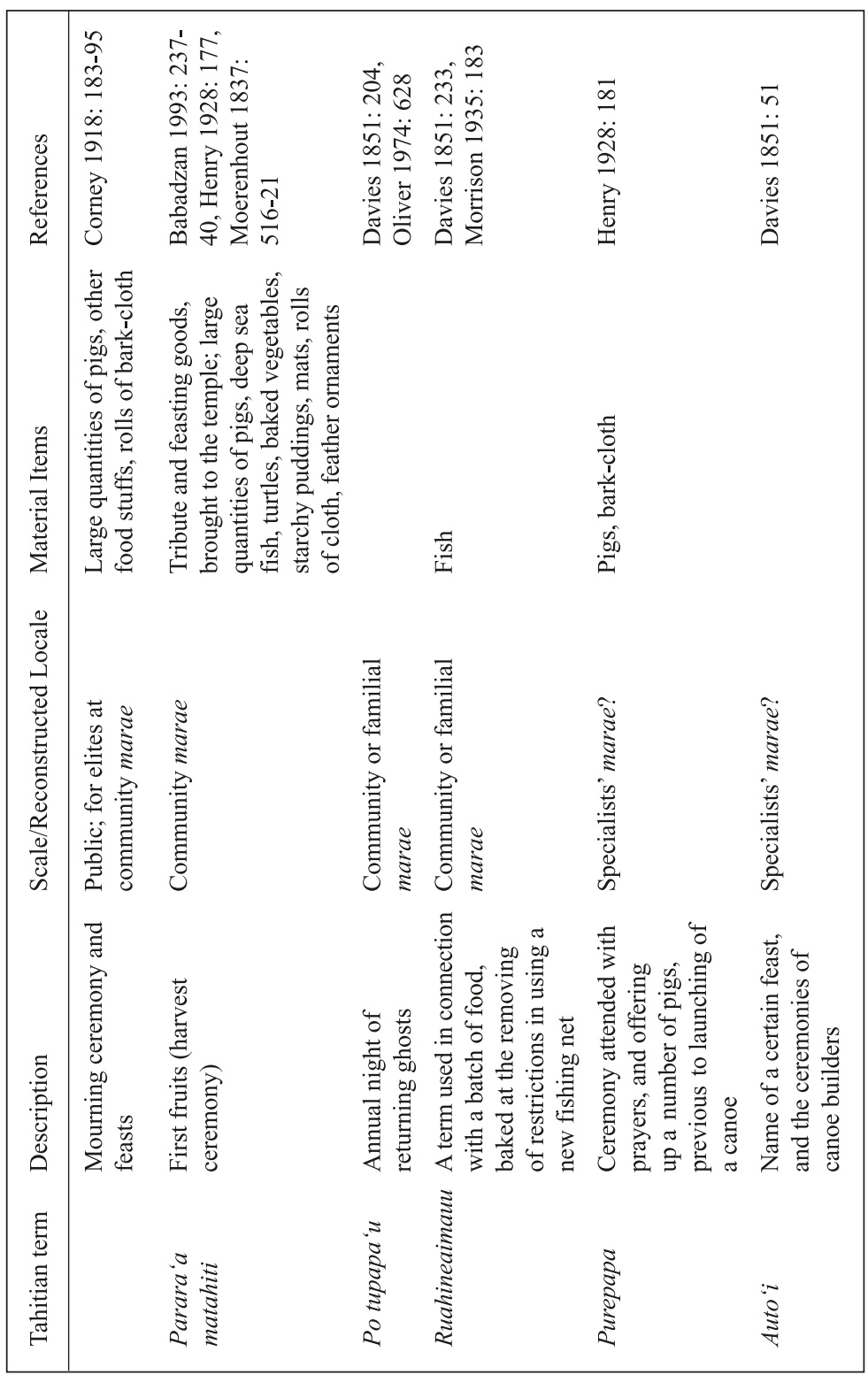




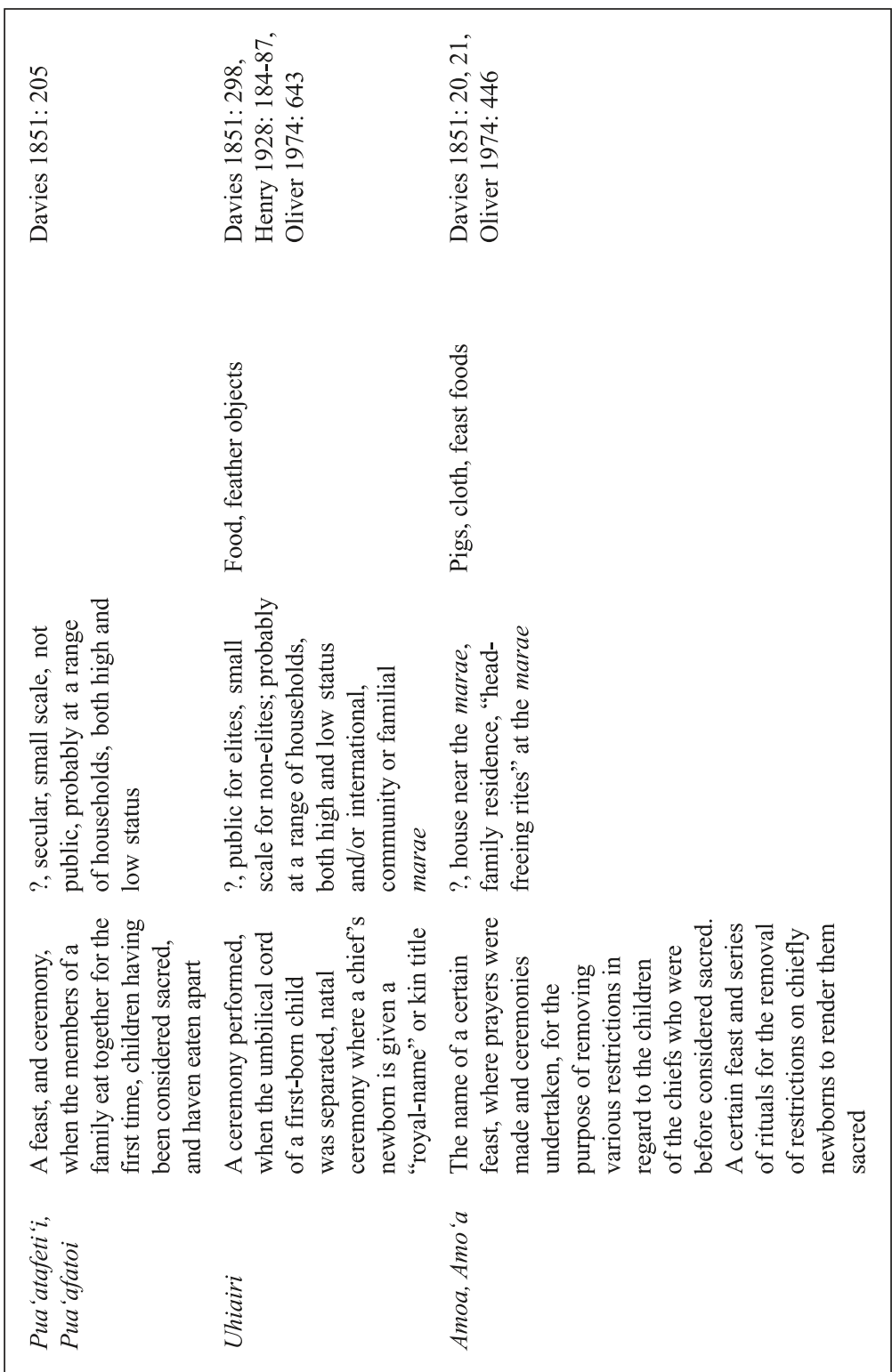




\section{Elite Feasts}

Ethnohistoric accounts indicate that elites, and particularly elite feasts, were provisioned by commoner labour and tribute (Corney 1914 [II]: 134, Henry 1928: 177, 260, 357, Oliver 1974: 635, 1010-11, 1071-72). Feasts were often integrated with Ma'ohi political events and socio-ritual rites (Oliver 1974). Lavish ceremonies where new chiefs were invested with power necessitated months of preparation. Commoner and elite households alike would have produced copious amounts of foodstuffs, such as pigs, plantains, breadfruit and starchy puddings ( $\mathrm{po}^{\prime} \mathrm{e}$ ), fancy clothing (including fine bark-cloth or tapa garments with feathers affixed to them), plaited mats and perhaps a new canoe for presentation at the investiture ceremony. One of the most sacred renewal ceremonies, the pa 'i atua or 'first fruits', would have taken place at community (district level) temples. Foodstuffs presented at the feast after the marae ritual included large quantities of pigs, deep-sea fish, turtles, baked vegetables and starchy puddings, as well as great numbers of mats, rolls of cloth and feather ornaments. Non-staple goods, particularly bark-cloth, also figured prominently in the articles demanded by the chiefs from households and communities as tribute for large-scale community-wide ceremonial events associated with feasting (Corney 1913 [I]: 357).

Glosses for Ma'ohi elite feasting refer to community-wide secular feasts and community-wide sacred feasts (Table 1); both likely had political connotations in elevating and supporting the socio-religious power of chiefly leaders. Some community feasts involved removing restrictions for important objects of high value, such as new fishing nets or a canoe. Such rituals may have taken place at specialists' temple sites, those that were dedicated to certain deities related to specific craft activities. Glosses for Ma'ohi communitywide sacred feasts sponsored by elites include rites of passage and life event ceremonies for rulers and members of their families, in addition to ceremonies of warfare and tribute. Such ceremonies took place on the largest and most elaborate temples, either of "international", "national" (royal), or "district" (community) level stature (Kahn and Kirch 2014: 35-39). Feasting events were likely held on spaces just adjacent to temples, either in the open air, or in specialised "eating sheds" (glossed as fare tama 'ara 'a; see Henry 1928: 176). Small feasts carried out at the end of a period of rahui 'restriction' took place directly on district level marae, where a pig was cooked and eaten on the spot (see also Ellis 1831 [II]: 93). Such feasting is likely to be associated with specialised architecture, including pavements or platforms where foodstuffs were consumed, or pavements where dances, songs and other amusements (wrestling, games) were carried out (Henry 1928: 239, Kahn 2005: 165). Ethnohistoric documents likewise suggest that ritual feasting could have taken place near priests' houses where ritual foods were cooked. Houses for ritual 
attendants are expected to be situated in close association with marae, and may be of either round-ended or rectangular form (Kahn 2015). Sumptuary nonstaple items presented to the chiefs as tribute, or exchanged in elite feasting ceremonies, including bark-cloth or other objects made from vegetal materials and fibre (e.g., mats), would have been produced in household contexts.

\section{Material Correlates of Society Island Feasting}

East Polynesian ethnographic data highlight that high status and highly valued foods often took central roles in feasts. These included fatty, fleshy animal foods (pig, dog, fowl, pelagic fish and turtle) and fermented breadfruit or puddings with coconut cream or oil. Kava, a psychoactive plant, may have been prepared and imbibed at feasting sites (Kirch and Green 2001, Thomas 1990). Following this, large quantities of such foods and drink disposed at one place would be highly indicative of feasting.

East Polynesian ethnographic and historic records, as well as archaeological data, suggest that many food stuffs would have been cooked or prepared in situ at both domestic and elite feasts in communal spaces removed from everyday cooking areas (Kahn field notes, 1997, Oliver 1974: 262, Suggs 1961: 72-73). Thus, the spatial context of cooking features, and their direct association with other sites types (sleeping houses, ritual structures, specialised houses), can be used to differentiate everyday cooking from food preparation associated with feasting events. Given the need for copious amounts of food, cooking or food preparation features associated with feasting, such as earth ovens, hearths and fermentation pits, should be larger or more abundant than those found in domestic cooking areas (see Ottino-Garanger 2006: 371, Fig. 6).

Ma'ohi sleeping houses served as the primary residence (Orliac 1982); such house sites typically are quite clean in their interior and have exterior but enclosed cookhouses, either directly attached to the house or on fronting terraces (Kahn 2005, 2007). Such every-day cooking areas typically had a small to moderate sized earth oven or hearth (or both) that were re-used time and again, as well as one to two food storage or fermentation pits. While cook sheds often are associated with charcoal, fire-cracked rock and sometimes shell and bone, these spaces were presumably regularly swept given their close association with sleeping houses which had to be maintained in a "clean" manner given tapu regulations. These data diverge from expected correlates of feasting areas, where we might expect larger sized and more frequent constellations of earth ovens, hearths and pits which were used to prepare copious amounts of food stuffs in short periods of time. That feast foods were all consumed and disposed of in one place (Henry 1928, Thomas 1990) likewise suggests that feasting debris will differ from everyday domestic remains. The intermittent but intensive use of feasting areas might 
lend themselves to less frequent cleaning or maintenance activities, resulting in large accumulations of cooking debris over short periods of time.

Unfortunately food items consumed at feasts in the Society Islands, as well as the majority of tribute items presented at such events (Table 1), were organic in their nature and will not preserve in inland valley contexts due to high rainfall and soil acidity. However, microfossil analyses should be able to retrieve signals of certain items, such as bark-cloth, kava and vegetal foodstuffs (Horrocks et al. 2015, Kahn et al. 2014). Due to these constraints, I focus on the most durable material correlates of Society Islands feasting, notably, the association of cooking features with non-domestic and/ or specialised or ritualised architecture. Site proxemics play an important role in defining site status, as temple sites, specialised ritual structures and ceremonial sites tend to be situated in elevated locales, as a way to protect individuals of high status who resided and used such sites. Equally important for identifying feasting locales are the size, frequency and placement of cooking features and associated cooking debris (earth oven rake-out, ash dumps, sheet deposits of charcoal and fire-cracked rock, etc.), as well as the nature of the associated archaeological deposits. Criteria for defining the function of sub-surface features can be found in Kahn (2005: 156-63, 180-82).

\section{SITE PROXEMICS AND EXCAVATION DATA FOR MA`OHI FEASTING}

Here I compare and contrast evidence for feasting events associated with 'Opunohu Valley, Mo'orea sites (Fig. 1). The case studies include two residential complexes with familial temples and an aggregate temple complex with community marae that functioned as a ritual-political centre.

\section{Amehiti Zone B}

The Zone B ceremonial and residential complex is found in the Amehiti District of the 'Opunohu Valley (Fig. 1). The Zone B complex includes numerous house sites and cooking sheds $(-322,-323,-326,-329 a, b, c)$ associated with households of varying rank, in addition to a specialised secular feasting area (-324), a familial temple (-325) and shrine (-338) of moderate elaboration, and dryland and irrigated agricultural complexes (-335, -337, -339) (Fig. 2). Based on site proxemics and excavation data, Zone B has been interpreted as the material remains of a corporate group (or house) of moderate status, who worshipped together at its ritual structures, planted together at its agricultural terraces, and feasted together at its specialised locales (Kahn and Kirch 2013).

Feasting remains were found on the elaborate terrace associated with the -325 temple. Here, test excavations at TP1 recovered two large earth ovens with multiple use events (Fig. 3, Table 2). The surrounding area had dense midden suggestive of in situ cooking practices (fire-cracked rock, charcoal, 


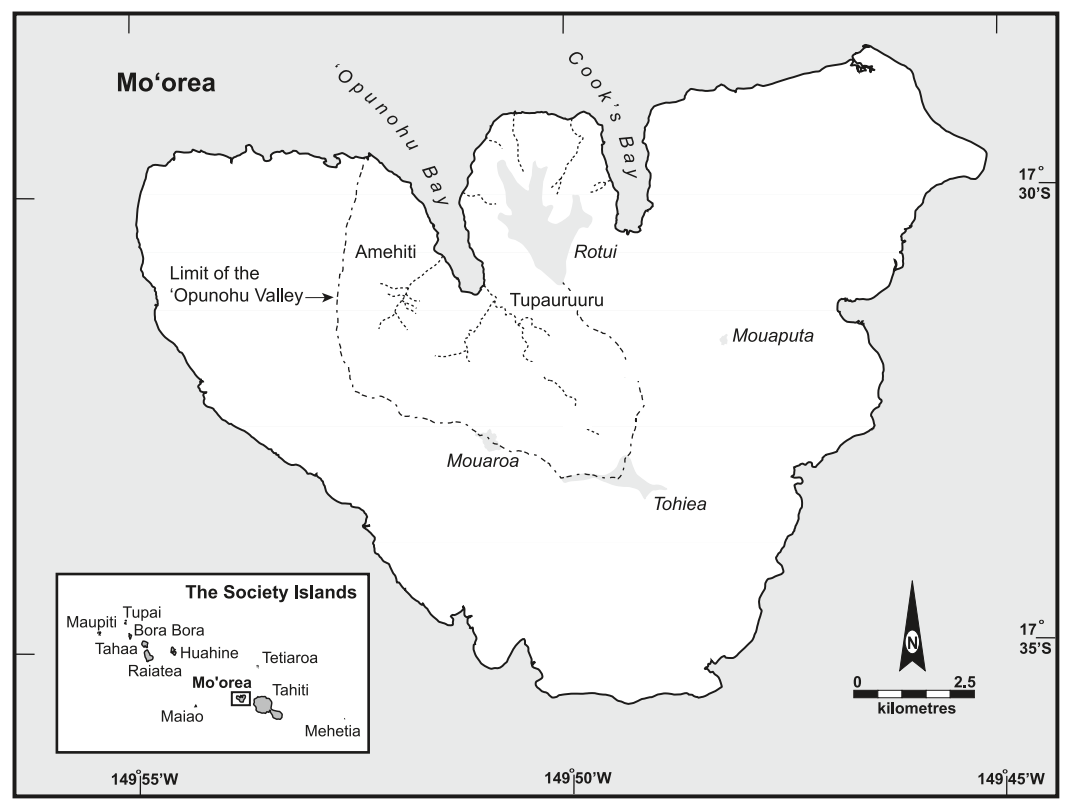

Figure 1. Overview of Mo'orea Island, showing the limits of the 'Opunohu Valley and the Amehiti and Tupauruuru political districts.

ash). Given their association with the familial temple, it is highly likely that these earth ovens are the result of communal ritual and feasting events sponsored by the headman of this corporate residential group. Given that -325 is situated at the most elevated point in this residential complex, such ritual feasting events would have both created a shared identity among residents of Zone B, while at the same time broadcasting the status and prestige of the headman to its lesser ranked members and neighbouring communities. Site -324 , an elaborate complex with two impressive terraces, is situated just below the -325 temple. The lower terrace (B) has a well-constructed pavement along its northeast limit, and a sub-surface cooking feature (hearth) was found at its extreme northeastern limit. Units excavated just adjacent to this hearth and along the mid-line portion of terrace B lacked charcoal and other artefacts, suggesting cleaning and maintenance activities. In contrast, the upper terrace (A) had deposits replete with charcoal, fire-cracked rock and ash. A moderate sized hearth and large earth oven were recovered in the excavations, in addition to a breadfruit fermentation pit. Given the limited 


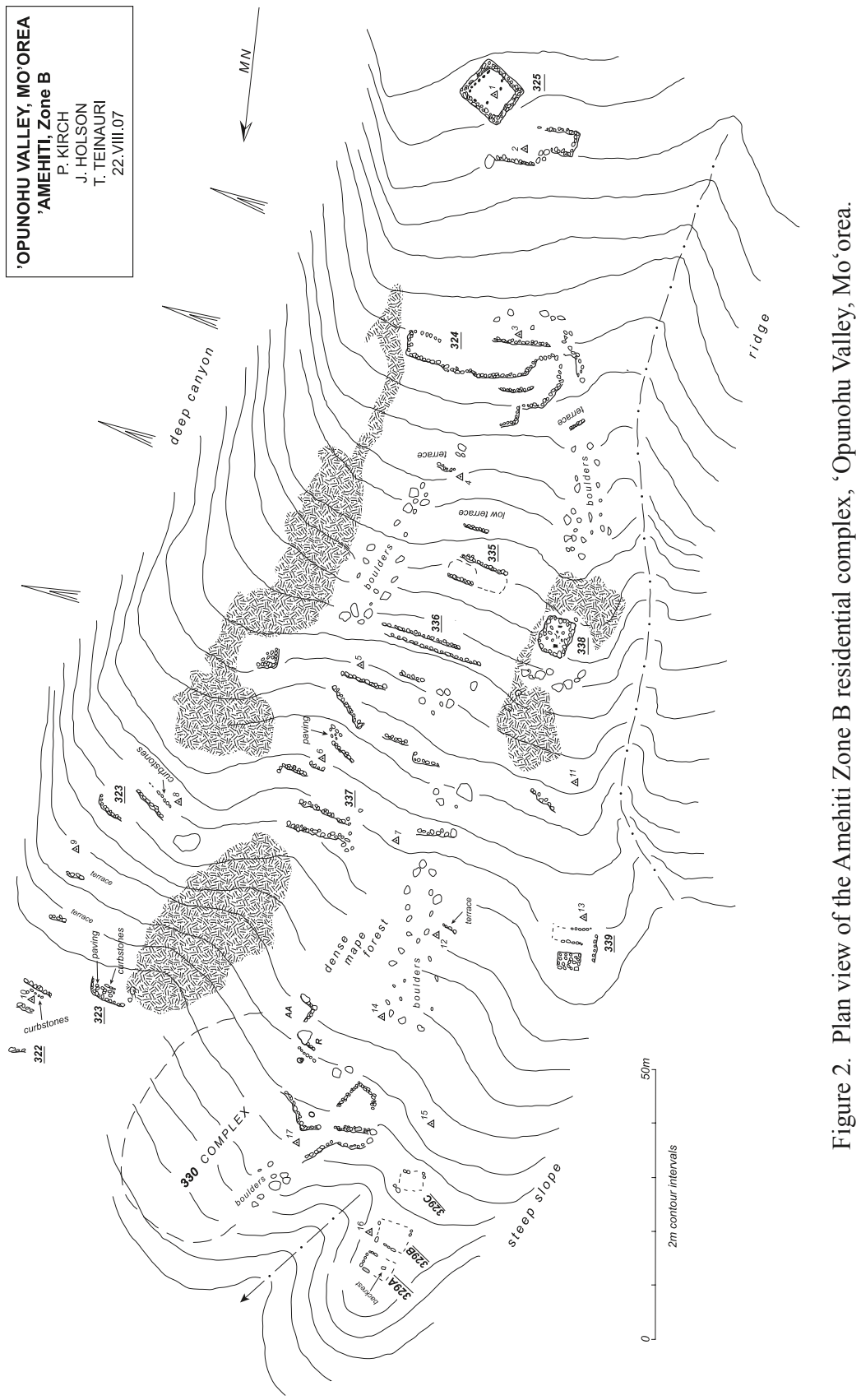


Jennifer G. Kahn 215

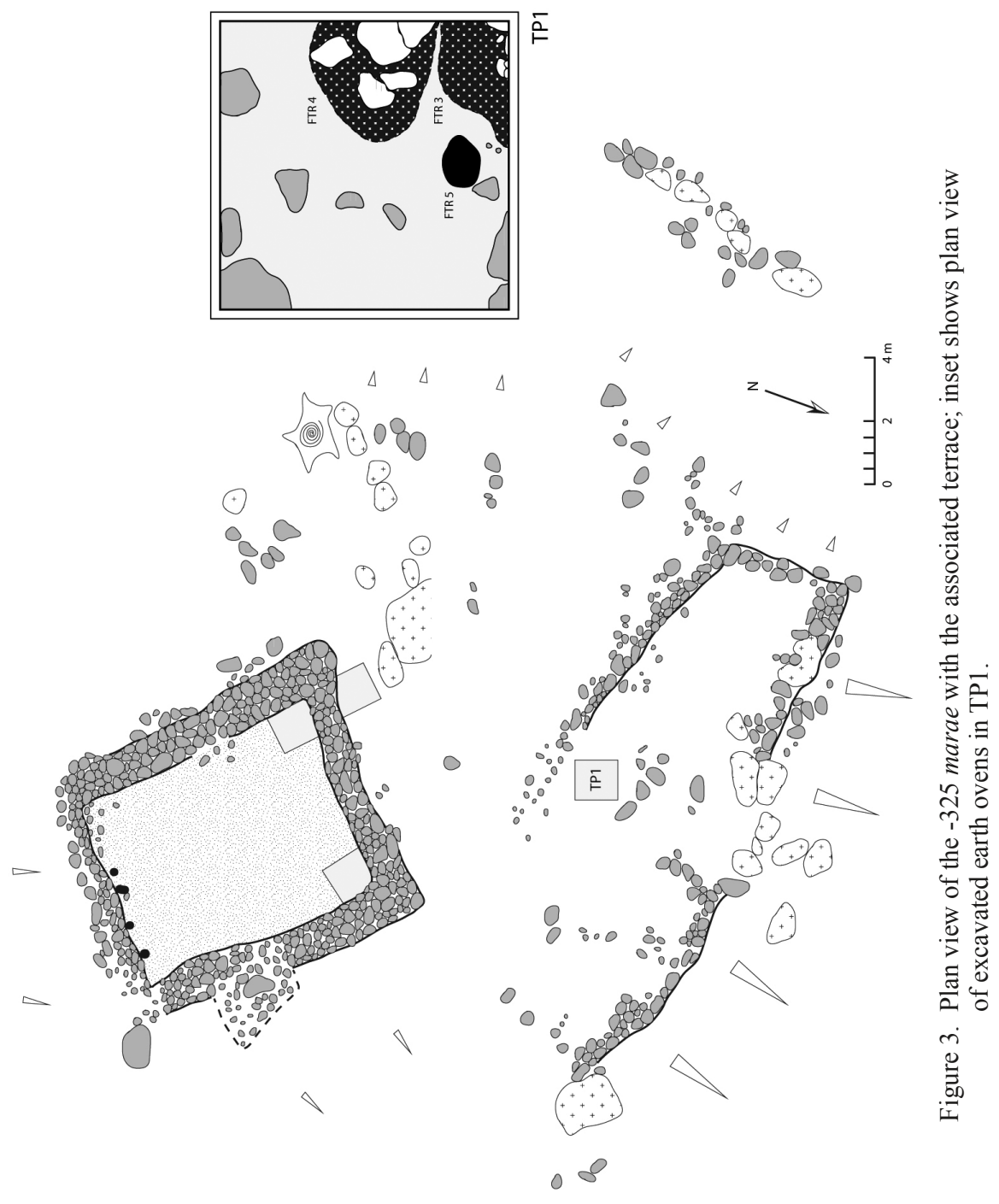




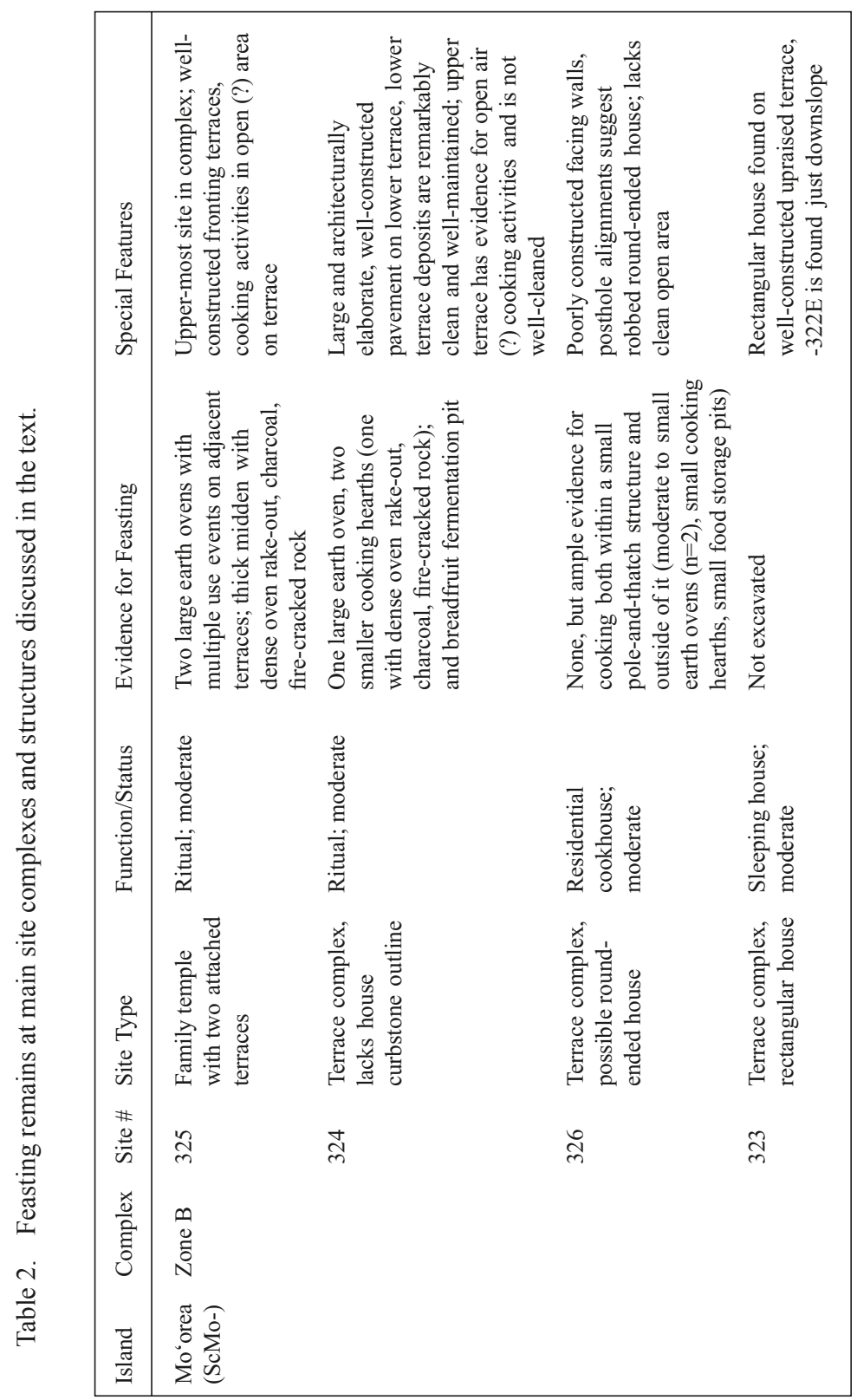


Jennifer G. Kahn 217

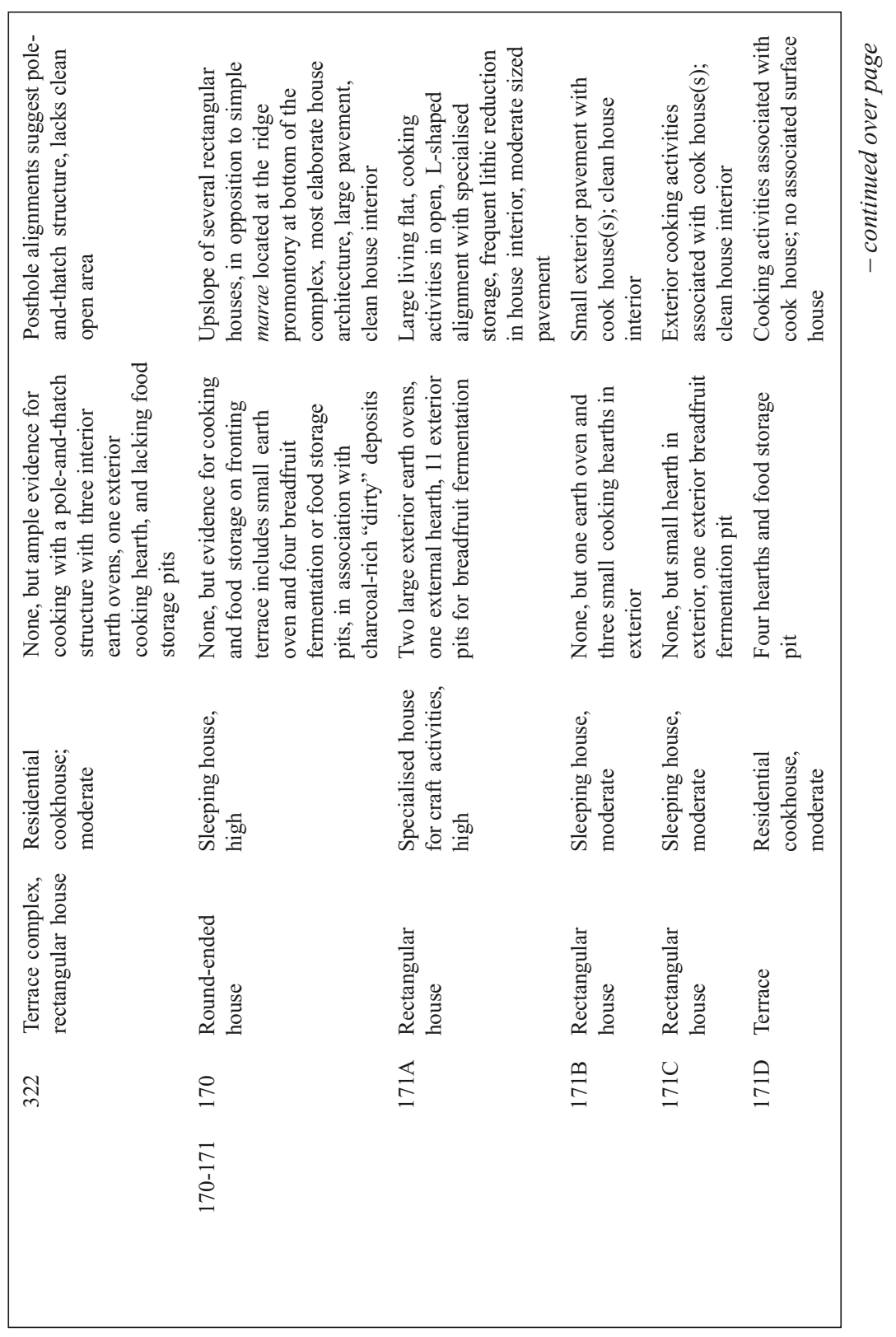




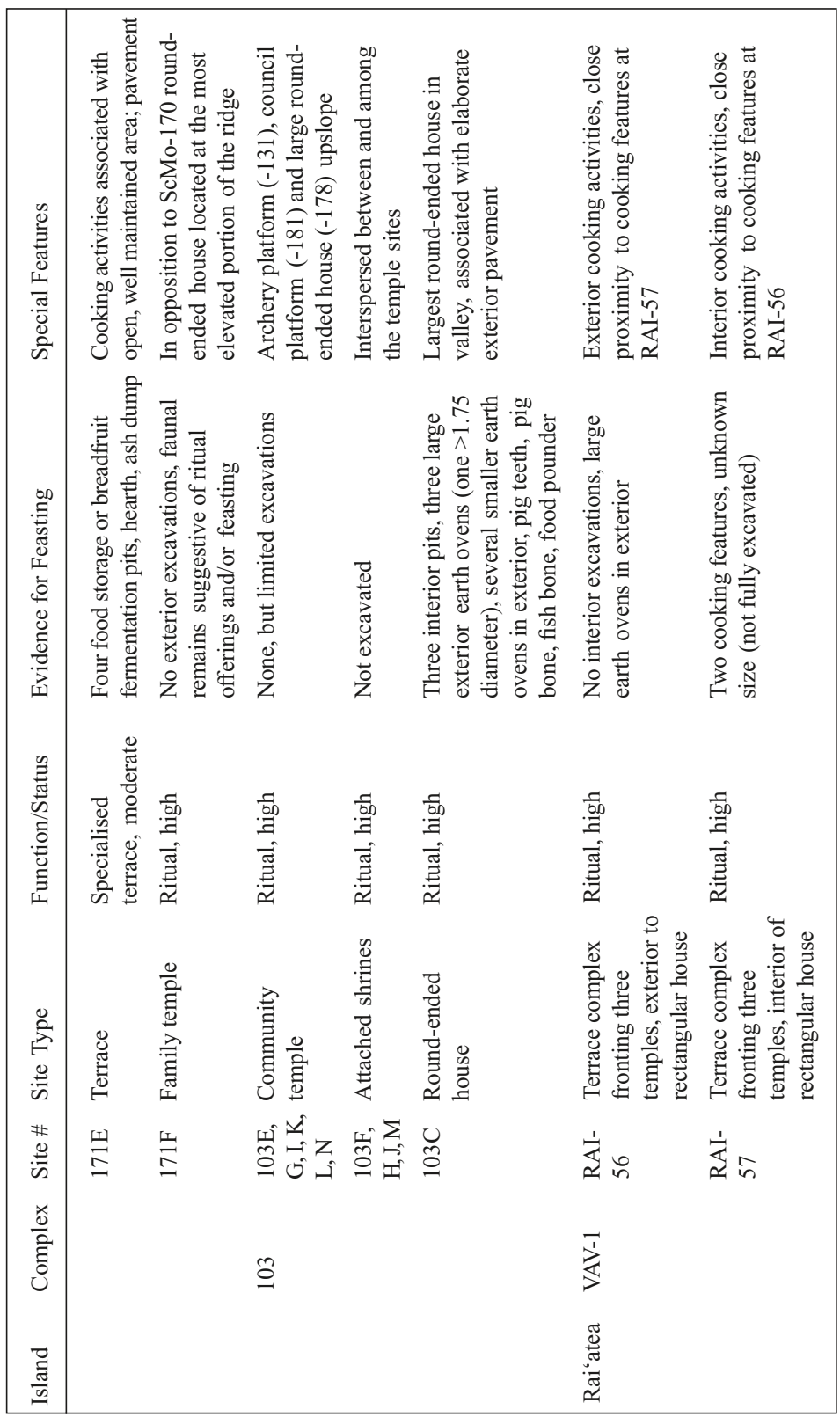


number of postholes recovered, these food preparation activities appear to have been carried out in the open air. It is likely that foods were produced on the upper terrace (A) for feasts that were situated on the lower terrace (B). These feasting activities were most likely associated with secular community events.

While not excavated, the architecture and layout of ScMo-323, a downslope house, suggest it served as a sleeping house for a moderate status household (Kahn and Kirch 2013). Just downslope of -323, excavations at the $-322 \mathrm{E}$ rectangular house revealed a house interior with numerous earth ovens and hearths but lacking food storage pits. Site -322E has been interpreted as a cookhouse for the residents of -323 (Kahn and Kirch 2013). In sum, areas interpreted as feasting locales, in contrast to domestic cookhouses, had moderate to large open-air food preparation facilities with large cooking features, in one case with food storage pits. In all cases the feasting food preparation facilities were not associated with sleeping structures. One feasting locale was found in association with a "clean" area devoid of cooking remains that could have served as a food consumption locale.

\section{Tupauruuru, ScMo-170/171}

The ScMo-170/171 residential complex is found in the heart of the Tupauruuru District. This residential complex includes four house sites, one round-ended $(-170)$ and three rectangular $(-171 \mathrm{~A}, \mathrm{~B}, \mathrm{C})$, in addition to stone-faced terraces with soil flats (-171D, E) (Fig. 4). A familial marae is found at the bottom of the complex, which also is the limit of the ridge, where it abuts the main stream. Terrace $-171 \mathrm{E}$ can be considered a fronting terrace to temple $-171 \mathrm{~F}$, given its close association to the southern enclosing wall of the temple, and the fact that the northern limit of $-171 \mathrm{~F}$ is bounded by a steep slope. Site proxemics and excavation data highlight that ScMo-170/171 was a high status residential complex (Kahn 2005, 2007).

As with Amehiti Zone B, feasting remains were recovered in two locales within -170/171, apparently differentiating zones of secular versus sacred feasting. Substantial evidence for supra-household food production and consumption was recovered along the large living flat associated with -171A (Fig. 5, Table 2). This rectangular house is situated below -170 , the round-ended house found at the most elevated point in the complex which is both large in size and well-elaborated architecturally. Site -171A, the most elevated of the rectangular houses in the complex, has a moderately sized exterior pavement along its northern limit. Excavations within the house yielded dense lithic remains suggestive of adze manufacture (Oakes 1994). Given that an outdoor adze production workshop was found on the exterior terrace adjacent to $-170,-171 \mathrm{~A}$ likely served as a specialised house for adze production activities (rather than as a sleeping house) (Kahn 2005, 2007). 


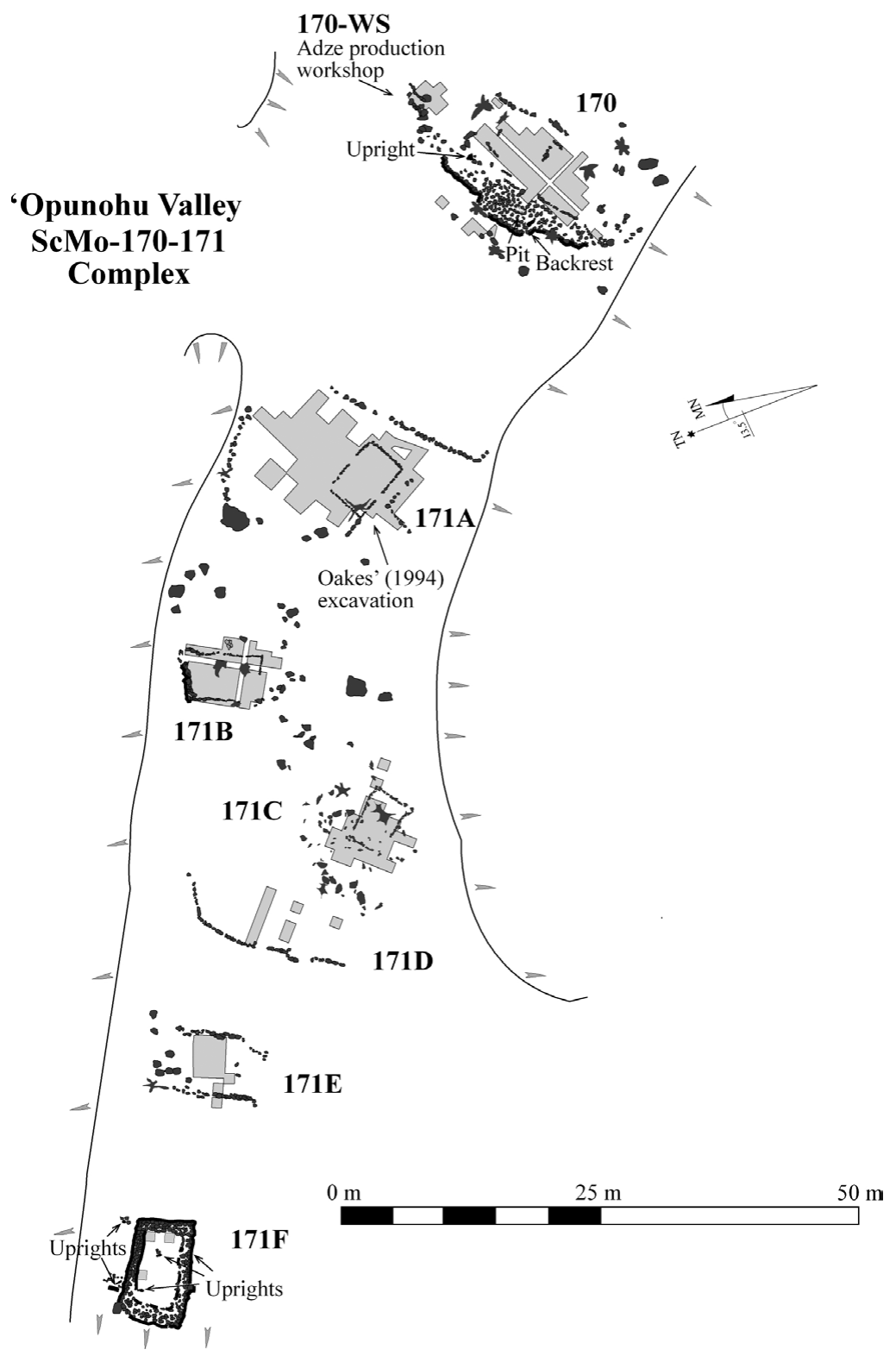

Figure 4. Plan view of $-170 / 171$ residential complex. 


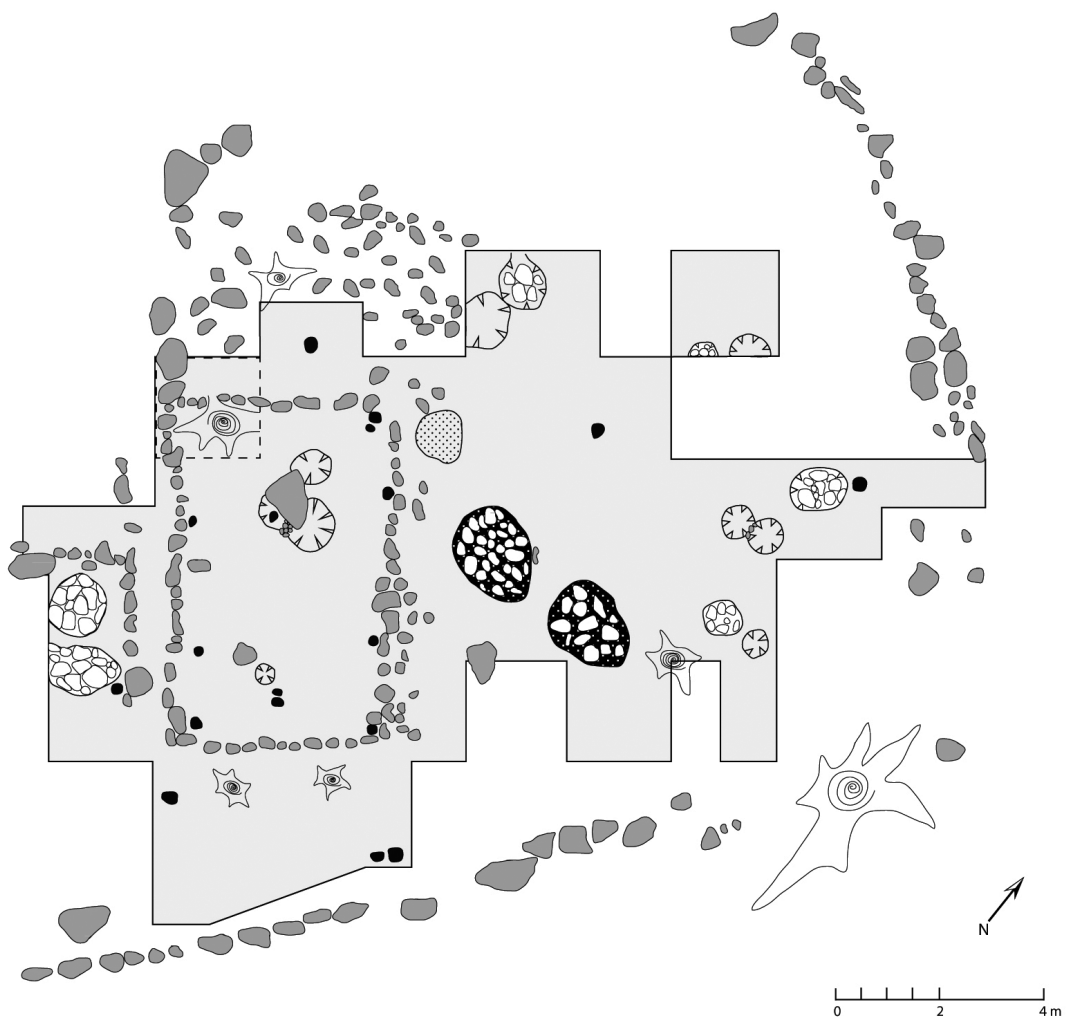

Figure 5. Plan view of -171A after excavation with sub-surface features.

Excavations revealed that the large living flat exterior to -171A had two large earth ovens and a cooking hearth, in addition to 11 pits for breadfruit fermentation, two of which were associated with an L-shaped stone alignment. These data demonstrate food production and consumption at levels beyond the needs of the residents of -170 and are indicative of domestic feasting. The intensity of food storage/fermentation pits signals material remains of the Polynesian "pudding complex", where fermented or semi-fermented starches were mixed with emollients such as coconut oil (Kirch and Green 2001), and sometimes cooked in earth ovens, to create specialty or luxury foods that featured prominently in Ma'ohi public feasts (Leach 2003). Given -171A's spatial location, its feasts appear to have been secular in nature and were likely sponsored by the headman of the corporate residential group residing in -170 . 


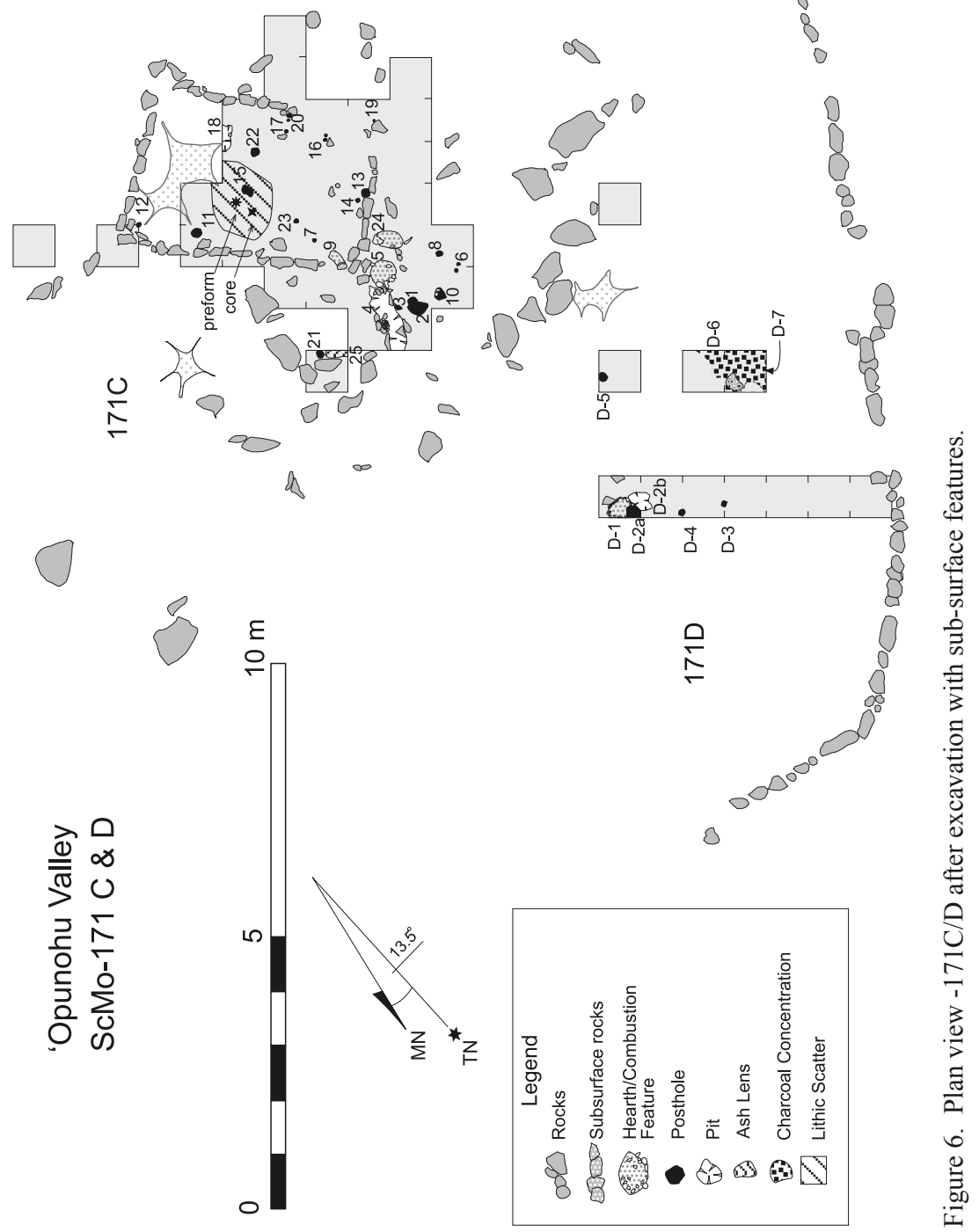


Jennifer G. Kahn 223

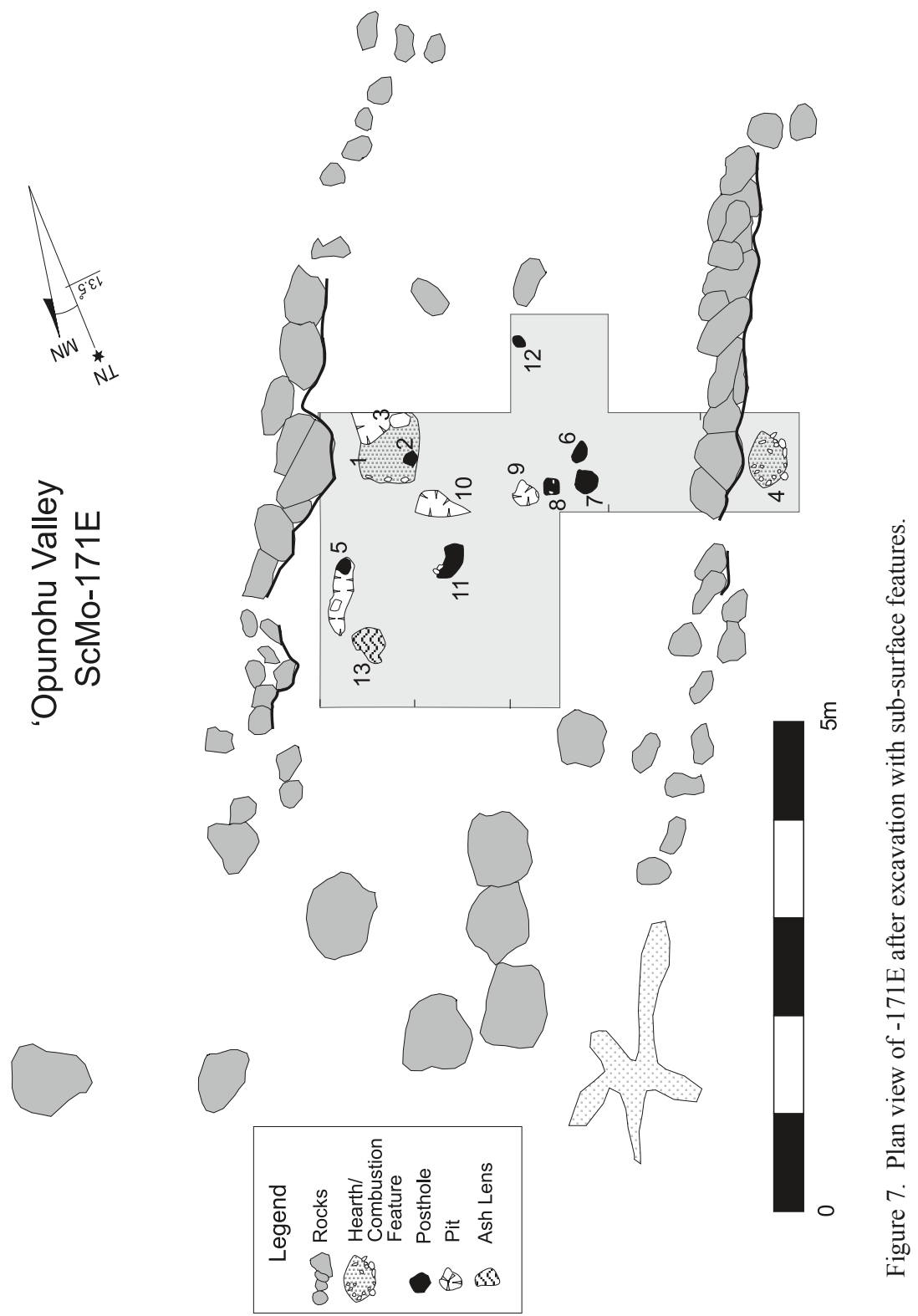


Feasting remains were also associated with terraces situated below the last rectangular sleeping house (-171C) and just above the small familial marae $(-171 \mathrm{~F})$ found at the bottom of the complex. Terraces -171D and -171E each included paired stone-faced terraces with interior soil flats; a portion of the $-171 \mathrm{E}$ soil flat had a moderately sized pavement (Fig. 7). At both locales, suites of food preparation activities not associated with formal sleeping houses were found, suggestive of public locales for communal activities. For example, excavations at $-171 \mathrm{D}$ recovered three hearths and a pit for food storage or fermentation, in association with substantial charcoal, oven rakeout, ash and fire-cracked rock. In a similar manner, -171E revealed substantial food preparation activities, including four food storage or fermentation pits, a cooking hearth and oven rake-out. However, in contrast to the "dirty" deposits recovered at $-171 \mathrm{D}$, some deposits at $-171 \mathrm{E}$, particularly those adjacent to the surface pavement, were "clean" and generally lacked fire-cracked rock or substantial charcoal. It seems likely that $-171 \mathrm{D}$ served as a communal food preparation area for feasting events that took place on -171E. Because these events were outside of the $-171 \mathrm{~F}$ temple enclosure, they may have been secular events led by the residential headman that brought together members of this extended corporate group. However, given that archaeological data and site proxemics suggest secular feasting was associated with high elevation and the residence of the headman (-170) and specialised structures (-171A), feasting events at $-171 \mathrm{E}$ could be interpreted as domestic ritual feasting events that were located in spatial opposition to secular domestic feasting events.

In sum, sleeping houses $-170,-171 \mathrm{~B},-171 \mathrm{C}$ each had cooking areas either directly attached to the exterior of the house, as with lower status houses $-171 \mathrm{~B}$ and $-171 \mathrm{C}$, or situated on a fronting terrace, as with higher status house -170 . These data conform to expectations for exterior cook-houses attached to specific households for everyday cooking. These data are in contrast to food preparation remains at -171A which are found in the open air in association with a specialised house and those at $-171 \mathrm{D}$ and $-171 \mathrm{E}$ which are found in open-air communal spaces. As with Amehiti Zone B, archaeological data suggest that feasting locales are more commonly associated with the presence of food storage or food fermentation pits or have higher frequencies of such sub-surface features than domestic cooking areas. As with Amehiti Zone B, feasting activities at $-170 / 171$ were also associated with well-constructed exterior pavements.

\section{Tupauruuru, ScMo-103}

ScMo-103 is situated in the middle of the Tupauruuru District lowlands. The complex is comprised of seven aggregated temples in addition to round-ended and rectangular house sites and raised stone platforms (Fig. 8). Round-ended 
Jennifer G. Kahn 225

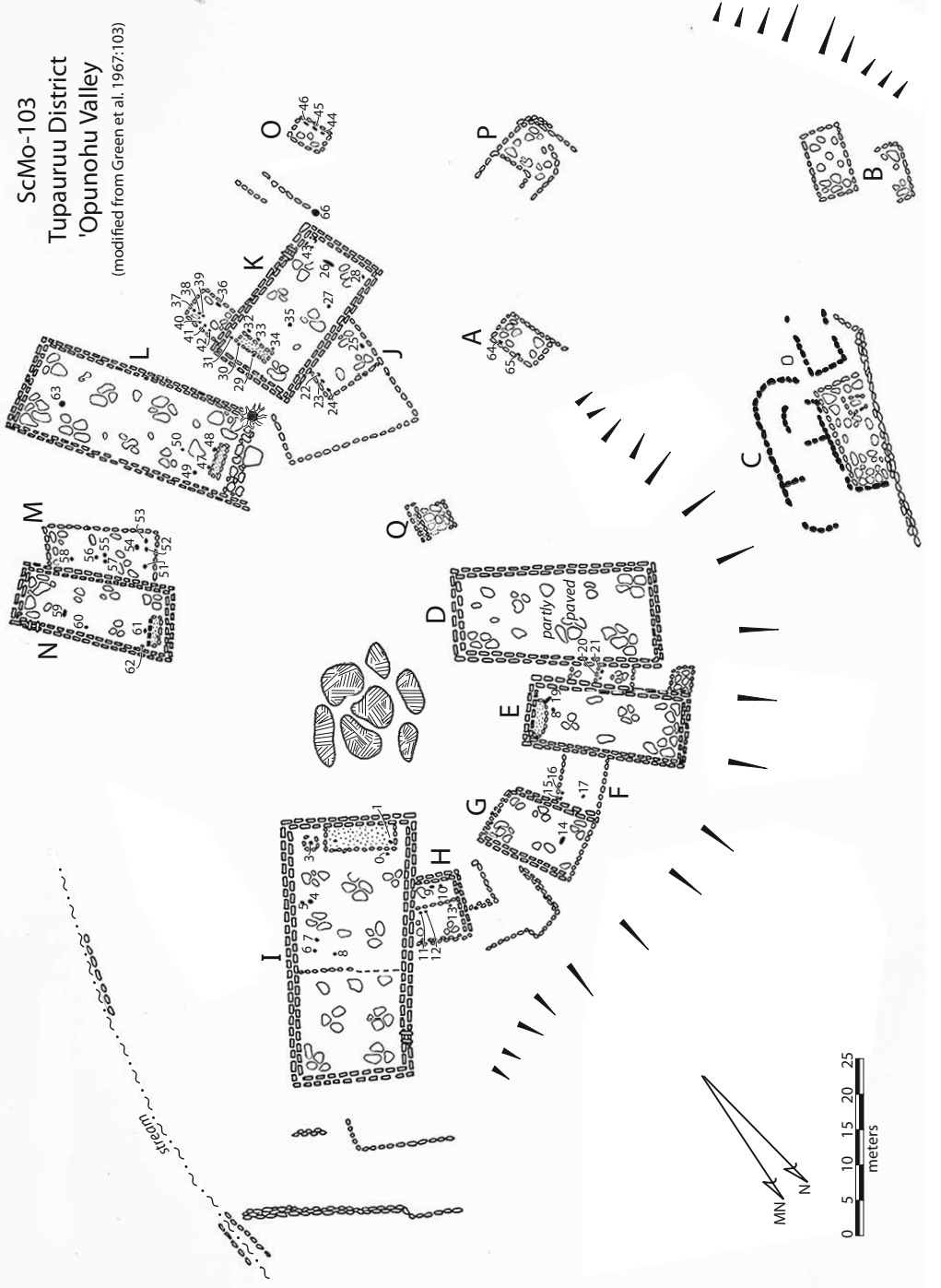

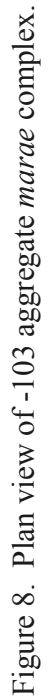


house site $-103 \mathrm{C}$ is exceptionally large and is associated with a sizeable, wellconstructed pavement. The complex is found adjacent to an archery platform (ScMo-131), another large round-ended house with an attached pavement (ScMo-178), and a chief's platform or council platform (ScMo-181). Council platforms (tahu ' $a$ - uти-риа ' $a$ or literally 'pig oven platform') signify an elite presence. These elaborate raised stone platforms served as loci for "national councils" of high chiefs, priests and landowners and also served as feasting areas (Kahn and Kirch 2014). Council platforms are rare in the valley and in all instances are associated with aggregate clusters of marae and other elite structures such as archery platforms (Green and Descantes 1989, Green et al. 1967, Kahn and Kirch 2014). Political deliberations or "national councils" held by chiefs at such platforms would be expected to be associated with feasting activities.

Green and colleagues (1967: 151) have argued that ScMo-103 served as a "focal point" or "major elite center" for settlement in Tupauruuru. I have argued that it served as one of four major ritual-political centres in the valley (Kahn 2011, Kahn and Kirch 2014), given that it is comprised of two or more elaborate temples in association with specialised sites such as archery platforms, council meeting platforms and large roundended houses and rectangular houses of a specialised function. Such major ritual-political centres would have been the loci of ceremonies sponsored by district level chiefs, as well as areas where tribute was brought to the chiefs by the surrounding community. Current excavation and survey data suggest that such ritual-political centres in the 'Opunohu Valley are often associated with specialised houses, including rectangular houses that served as residences for ritual practitioners (Kahn 2013, 2015, Kahn and Kirch 2014; see also Orliac 1982: 164). Oral traditions describe how high priests could be attached to specific elite temple sites (such as community level marae), where participation in ritual was restricted to high status persons (Babadzan 1993, Henry 1928: 144). As Table 1 suggests, ceremonies at such temples were often followed by elaborate community feasts.

Green and Davidson's excavations at round-ended house site ScMo$103 \mathrm{C}$ recovered numerous breadfruit storage pits in addition to numerous exceptionally large earth ovens associated with charcoal, ash and fire-cracked rock (Table 2). Green and colleagues (1967: 138) interpreted the quantity and size of these features as suggestive of "lavish entertaining". Site -103C has been interpreted as a fare i 'a manaha, a house to store sacred items used in marae ceremonies (Green 1996, Orliac 1982: 237). The size, frequency and context of its cooking features are suggestive of a feasting locale. Feasting events at $-103 \mathrm{C}$ were likely both community-wide secular and ritual events 
given their association with an aggregate marae complex of some elaboration. I recovered similar feasting events at a second major ritual-political complex in the 'Opunohu Valley (ScMo-124), at a higher elevation in the Tupauruuru District. There, community-wide ritual feasting took place on a large terrace fronting two elaborate marae and adjacent to two elaborate pavements and a rectangular priest's house (Kahn 2015: 74, Kahn and Kirch 2014), while community-wide secular feasting took place in front of a council platform (Kahn and Kirch 2014).

The -103 feasting facilities share similarities with those found at Amehiti Zone B and 170/171. These include evidence for cooking facilities unassociated with sleeping houses, but found in close proximity to communal areas fronting marae, or to specialised structures such as priests' houses and council platforms. The -103 data support the hypothesis that feasting locales will have frequent and large cooking features and storage pits in associated with dispersed debris from cooking activities such as ash, charcoal, and fire-cracked rock.

\section{EXTRA-AREAL COMPARISONS}

Having highlighted the nature of feasting events at both community and familial level temples on Mo'orea, in addition to those found at residential complexes, I briefly turn to excavation data from other islands in the archipelago to parse out regional patterns. A survey of excavation reports from Tahiti illustrates that large earth ovens and hearths have been recovered in temple contexts, both within elaborate temple enclosures (community level marae), as well as near or within the $a h u$ 'altar' (Belcaguy 1988, Garanger 1971, 1975: 43-44). Their context is highly suggestive of communal ritual feasting events, some of which may have taken place when architectural features of the temple, particularly the altar, were enlarged or elaborated. Data from the Papeno'o Valley, particularly from TPP06 (Chazine 1978: Figures 35-38), highlight that terraces in front of large aggregate marae complexes (community level temples) were used for feasting events. The latter were likely associated with community secular feasts which followed rituals on the marae, similar to patterns found at Site-342, Amehiti Zone B.

Turning to the Leeward Society Islands, Edwards's (1988) survey of $\mathrm{Fa}^{\prime}$ aroa Valley, Rai'atea recovered numerous temple complexes of varying size and complexity. He argued that the VAV-1 complex was one of two extensive ceremonial complexes in the valley with elaborate temples and house sites (1988: 19), in effect, similar to the ritual-political centres found in the 'Opunohu Valley. Fa' aroa survey data suggest that these two sizeable aggregate marae centres had large ritual structures functioning as district level temples. 


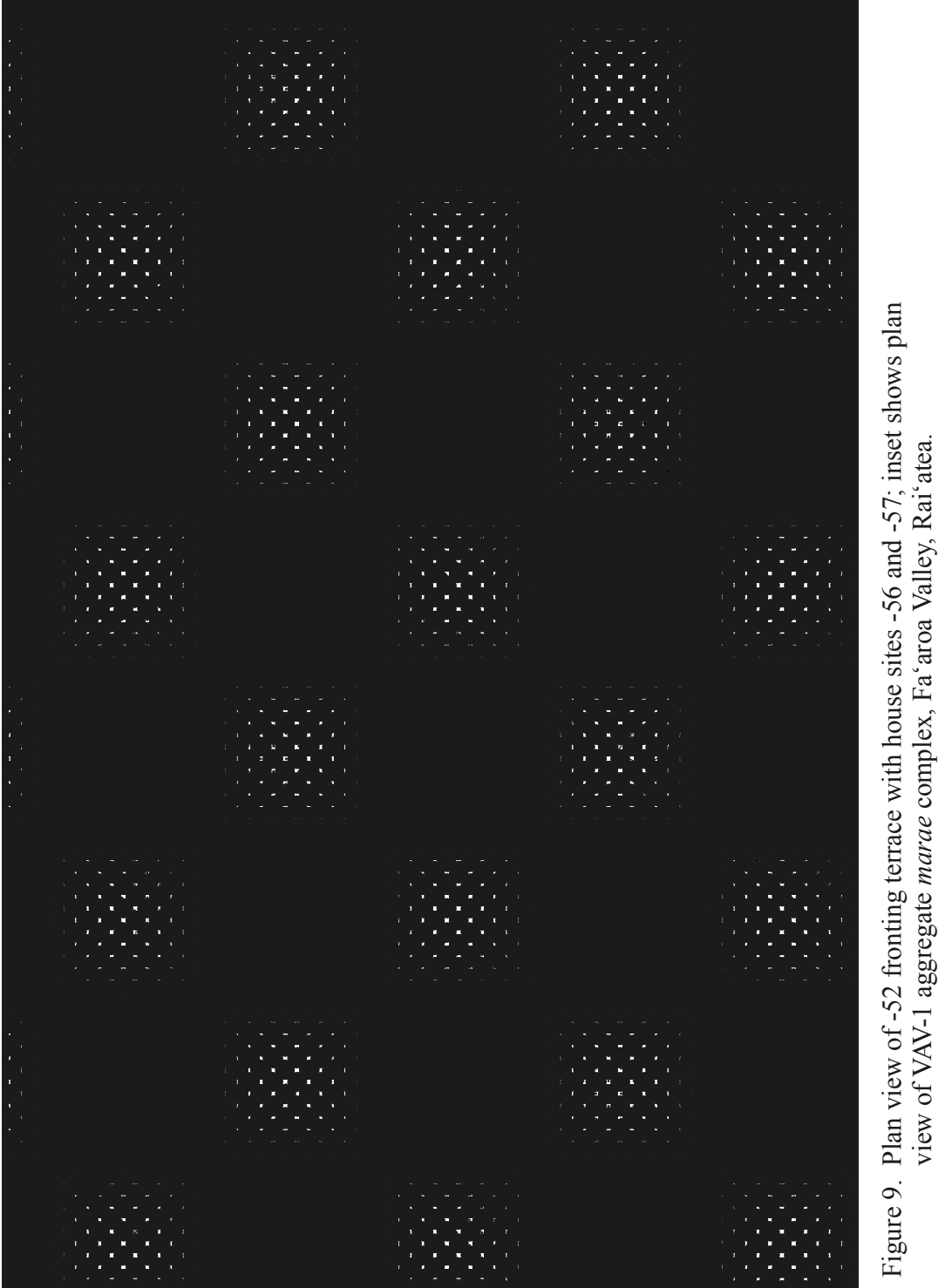



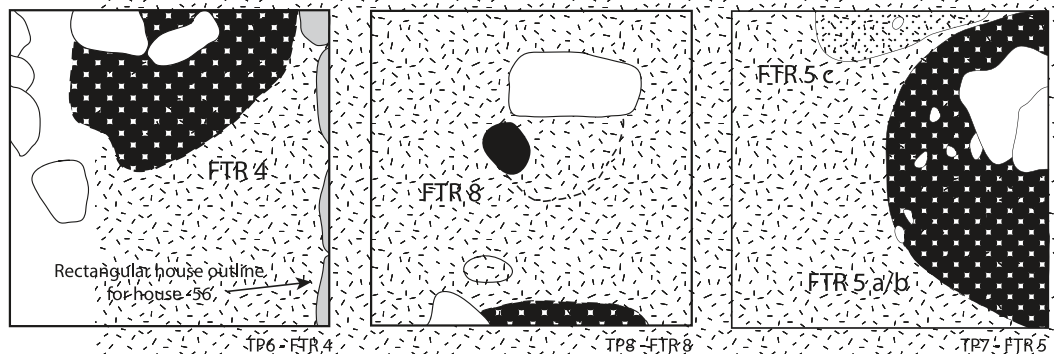

Figure 10. Sub-surface features associated with rectangular house sites -56 and -57 , VAV-1 aggregate complex.

The eastern zone of the VAV-1 complex includes three elaborate temples situated on an extensive and well-constructed terrace which fronts the marae (Fig. 9). Several pavements and at least four rectangular houses are found on this fronting terrace. My recent excavations at two of these rectangular houses (RAI-56, -57) uncovered extensive evidence for food preparation activities, including four cooking features, two of which were sizeable earth ovens (Fig. 10).

One of the cooking areas was exterior to a rectangular house, while the other was found within a rectangular house. Both food preparation areas had extensive sheet midden replete with oven rake-out, fire-cracked rock and ash. Given the close association of these cooking areas to wellconstructed pavements on fronting terraces, and the sites' close association with elaborate marae, it seems likely that they represent communal secular feasting locales. Rectangular house sites -56 and -57 may have in fact served as fare tama 'ara ' $a$ or specialised eating sheds known to have been used in elite feasts in the Society Islands.

\section{TEMPORAL TRENDS}

Here I discuss dated feasting contexts (as reported in other publications) to assess whether domestic or supra-household ceremonial feasting intensified in the Society Islands through time. In terms of Amehiti Zone B, ritual and secular feasting at sites -325 and -324 calibrates to between the mid-15th to mid-17th centuries at 2 sigma (Kahn and Kirch 2013). Feasting events at -171A post-date AD 1641, and are also relatively late in the Society Islands sequence (Oakes 1994: 77), while the -171E and -171D contexts have not yet been dated. 
Feasting events taking place in aggregate marae complexes interpreted as ritual-political centres also calibrate to the late prehistoric period. Feasting contexts at $-103 \mathrm{C}$, based on a large earth oven calibrated to the mid-17th to mid-18th centuries (Kahn 2011), most likely date to the period just prior to European contact (pre-AD 1767). Feasting events at a second major ritualpolitical centre in the 'Opunohu Valley, ScMo-124, include dates from earth ovens associated with a priest's house. Radiocarbon samples from these two earth ovens most likely date to between AD 1690-1730 (Kahn and Kirch 2014: 191-92). Structures or feasting events in the Fa'aroa Valley VAV-1 aggregate marae complex have yet to be dated. However, the surface architecture of two of the associated marae, namely Acropora (coral) veneer facing of the $a h u$, suggest that the complex was constructed and used late in the Society Islands sequence, post AD 1620 (see Kahn and Kirch 2014, Sharp et al. 2010).

Clearly more residential and ceremonial feasting contexts must be dated in the Society Islands to develop a refined chronology for these important socio-political events. Current data tentatively suggest that domestic feasting at elite house sites began as early as the mid-15th century and likely became intensified in the mid-17th century. Lepofsky and Kahn (2011) and others (Green 1996, Kahn 2014) argue that status differences among and between Ma'ohi residential complexes become pronounced by the mid-1400s, a time of major inland expansion in the archipelago, when communities established temples and house sites in interior valleys. Thus, small-scale household feasting correlates with a period of increasing status differentiation among households and tentatively suggests that local scale feasting events ultimately contributed to these larger social transformations.

By the mid-1600s, Ma'ohi elites had increasing control over subsistence production, both at the local and community scales (Lepofsky and Kahn 2011). Feasting at aggregate marae complexes intensified in the 17th century and continued up to the era of European contact (AD 1767). This was a period of rising political centralisation in the Society Islands, characterised by increasing political power of ruling elites such as paramount and district level chiefs and ritual specialists. Archipelago-wide data suggest that feasting was increasingly exploited by the Ma'ohi elite class in later prehistory as a means of centralising their political power, particularly post-AD 1650, a chaotic period with intensive warfare ending in the unification of the Tahiti and Mo'orea chiefdoms, and a period of religious upheaval with the translocation of the 'Oro war cult from the Leeward Islands (Kahn 2010, Maric 2012, Wallin 2014). These trends mirror worldwide patterns, where feasting, as both an integrative and diffractive political strategy, can intensify during periods of inter- and intra- polity conflict and competition and periods of socio-religious upheaval (Junker 1999, Schachner 2001). It appears that Ma'ohi feasting had 
broader social ramifications, ultimately leading to increasing social hierarchy at both the local (household) and community (district) scales. Such patterns have been documented in other complex societies, where feasting activities tend to proliferate as political centralisation intensifies (Chicoine 2011, Knudsen et al. 2012, Kolb 1994, 2006).

$$
* * *
$$

The Society Islands archaeological case studies illuminate several points with respect to the role of feasting in late prehistoric Ma'ohi society. In terms of context, feasting events can be found within secular locales, including communal spaces in residential complexes, sometimes in close association with the headman's residence, and terraces attached to, or fronting, temple complexes, sometimes in association with priest's houses. Feasting events are also associated with ritual locales, such as the interior of temple enclosures or in close association to temple altars, in addition to political locales, such as council platforms. These archaeological data confirm hypotheses developed from the ethnographic record, notably that feasting was a strategy used by household leaders and regional political leaders, including chiefs and the religious elite (priests), at both the local and community (or district) level. It is clear that Ma'ohi feasting events empowered different social groups at different social scales.

The archaeological case studies highlight the importance of context and site proxemics in both the identification of feasting activities and interpreting their specific function, yet sampling issues remain. Excavation data suggest that Ma'ohi feasting was associated not only with open-air cooking facilities, often containing large and numerous earth ovens and hearths, but commonly with pits for storing and preparing starchy root crops and fruits that would be transformed into luxury puddings. Such creamy puddings played important roles as feast foods throughout Polynesia (Kirch and Green 2001).

Since we lack well-preserved material remains of feasting, including detailed evidence of the type, quality and quantity of foodstuffs, it is difficult to parse out feast type or feast function without relying heavily on the size and frequency of food preparation facilities, their relationship to specialised architecture and site proxemics. For example, current excavation data from the 'Opunohu Valley indicate that small-scale domestic feasting was hosted by upper class households in communal spaces with pavements, however, additional excavations at lower status house sites may reveal other evidence for domestic feasting. Current data also suggest that local headmen hosted both secular and ritual feasts to reify and unify the corporate group, perhaps in face of tensions between households that may have arisen as a result of 
varied access to material and immaterial symbols of wealth and status (Kahn 2005, 2007). Such small-scale domestic feasts likely materialised the ritual and socio-economic status of the residential headman to other members of the corporate group and visiting neighbours. This hypothesis must be tested with additional excavations at residential complexes of varying status to understand the "reach" of feasting events among and between domestic complexes of varying status.

At the archipelago-wide scale, the close association of ritual-political centres with feasting activities likewise supports how district or community level chiefs and high-status priests hosted feasting events as a means to extend their economic or political authority, as well as a means to engage in community building. Within these contexts, communal and secular feasting was often associated with specialised facilities, including elaborate pavements, specialised houses, priests' houses and elaborate terraces fronting marae, similar to data for supra-household feasting elsewhere in Polynesia and in other complex societies. In these contexts, community members, some of whom could not directly participate in the ritual events at the ceremonial marae, could be entertained by the largesse of political and ritual leaders with foodstuffs, oratory and entertainment. Community members reciprocated by literally providing the fruits of their labours as the foodstuffs to be consumed during the feasting events.

While more work is needed to clarify these trends, the political nature of Ma'ohi communal feasting is most strongly materialised in its association with council platforms in the two well-excavated political centres of the 'Opunohu Valley. Ethnohistoric texts describe how social units competed against one another to produce the best tribute in order to please the gods, suggesting that at least at the community level, feasting spurred the intensification of domestic production (Henry 1928: 174-75) and perhaps led to other social transformations. Certainly, intensive elite feasting in Hawaiian temples supported the ideological power of chiefs in illustrating their role as mediators between the greater populace and the gods (Kolb 1994), and we can expect that Ma'ohi chiefs profited in a similar manner from hosting sacred and secular community feasts. One possibility is that the chiefly lineages controlling the four major political-ritual centres in the 'Opunohu Valley were carrying out competitive corporate feasting as a strategy for indebting their neighbouring chiefs, but also as a means of alliance building and marriage exchange. These trends intensified after AD 1650, a period of major regional social upheaval and warfare that resulted in regional political centralisation and the introduction of the 'Oro war cult from the Leeward Islands.

Finally, there is some suggestion that the specific function of feasting differed at monumental architecture of varying scale and complexity, for 
example, at familial temples versus larger, more elaborate community or district temples. At larger community aggregate temple complexes, archaeological evidence and ethnographic analogy for feasting in the late prehistoric period illustrate how Ma'ohi chiefly lineages actively demonstrated their social power by competing in cyclical rituals associated with tribute display and competitive feasting. Yet at familial level temples, archaeological evidence and ethnographic analogy suggest that household headmen utilised feasting as a means of status display as well as a signal of hospitality and of belonging to a particular social group. Thus, at both the household and community scales, Ma'ohi feasting is strongly correlated, but not uniquely associated, with ceremonial sites. Feasting in the late prehistoric Society Islands chiefdoms served varied secular and sacred functions. Such events actively solidified local and community level leaders' economic, socio-political and ideological power in varied ceremonial contexts and likely contributed to the high degree of political centralisation seen in the period just prior to European contact.

\section{ACKNOWLEDGEMENTS}

The 'Opunohu Valley and Rai' atea fieldwork was funded by NSF grant BCS\#0725173 and $\mathrm{CNH} \# 1313830$. Permission to conduct research in French Polynesia was granted by the Service de la Culture et du Patrimoine (SCP), the Ministère de la Recherche, le Service du Développement Rurale, the Délégation à la Recherche of the French Polynesian government and the Délégation Régionale à Recherche et à la Technologie of the French High-Commissioner. I thank Belona Mou and Tamara Maric, archaeologists with the SCP, for their aid in facilitating research and export permits. Diana Izdebeski redrafted many of the figures. Brian Hayden, an anonymous reviewer and JPS Editor Melinda Allen provided detailed and instructive comments on an earlier draft of this article.

\section{REFERENCES CITED}

Babadzan, Alain, 1993. Les Dépouilles des Dieux: Essai sur la Religion Tahitienne a l'Epoque de la Découverte. Paris: Editions de La Maison des Sciences de L'Homme.

Belcaguy, Horacio, 1988. Les Marae des Iles de la Société, Tuamotu, Australes et Gambier dans la Litterature Archeologiue et Ethnohistorique. Memoire de Maîtrise, Universite Paris I.

Blitz, John H., 1993. Big pots for big shots: Feasting and storage in a Mississippian community. American Antiquity 58 (1): 80-96.

Chazine, Jean-Michel, 1978. Contribution à l'Etude des Anciennes Structures d'Habitat dans une Vallée de Tahiti. Unpublished report, Department of Archives, CPSH. Punaauia, Tahiti. 
Chicoine, D., 2011. Feasting landscapes and political economy at the Early Horizon center of Huambacho, Nepeña Valley, Peru. Journal of Anthropological Archaeology 30 (3): 432-53.

Corney, Bolton Glanville [editor and translator], 1913. The Quest and Occupation of Tahiti by Emissaries of Spain During the Years 1772-1776 (Vol. I). London: The Hakluyt Society.

-1914. The Quest and Occupation of Tahiti by Emissaries of Spain During the Years 1772-1776, Told in Dispatches and Other Contemporary Documents (Vol. II). London: The Hakluyt Society.

1918 The Quest and Occupation of Tahiti by Emissaries of Spain During the Years 1772-1776 (Vol. III). London: The Hakluyt Society.

Davies, John, 1851. A Tahitian and English Dictionary with Introductory Remarks on the Polynesian Language and a Short Grammar of the Tahitian Dialect with an Appendix. Papeete: Haere Po No Tahiti.

Dietler, Michael, 2001. Theorizing the feast: Rituals of consumption, commensal politics, and power in African contexts. In Michael Dietler and Brian Hayden (eds), Feasts: Archaeological and Ethnographic Perspectives on Food, Politics, and Power. Washington, DC: Smithsonian Institution Press, pp. 65-114.

Dietler, Michael and Brian Hayden, 2001. Digesting the feast-good to eat, good to drink, good to think: An introduction. In Michael Dietler and Brian Hayden (eds), Feasts: Archaeological and Ethnographic Perspectives on Food, Politics, and Power. Washington, DC: Smithsonian Institution Press, pp. 1-20.

Donna J., 2010. Fine dining and fabulous atmosphere: Feasting facilities and political interaction in the Wari realm. In E.A. Klarich (ed.), Inside Ancient Kitchens: New Directions in the Study of Daily Meals and Feasts. Boulder: University Press of Colorado, pp. 83-109.

Edwards, Edmundo, 1988. Fa'aroa: Vallées de la Vaiava de La Huaroroet de la Papepao, Ile de Raiatea. Unpublished report, Department of Archives, CPSH. Punaauia, Tahiti.

Emerson, T.E. 2008. Locating American Indian religion at Cahokia and beyond. (T.E. Emerson, S.M. Alt, T.R. Pauketat). In Lars Fogelin (ed), Religion, Archaeology, and the Material World. Occasional Paper No. 36. Carbondale, Illinois: Center for Archaeological Investigations, Southern Illinois University, pp. 216-36.

Ellis, William, 1831. Polynesian Researches During a Residence of Nearly Eight Years in the Society and Sandwich Islands. 4 vols. London: Fisher, Son \& Jackson.

Garanger, José, 1971. Rapport d'Activités pour l'Année: 1971 (Vallée de Aiurua). Unpublished report, Centre National de la Recherche Scientifique (CNRS) ERA no. 52, RCP No. 259.

-1975. Marae Ta'ata: Travaux Effectués par la Mission Archéologique ORSTOM - CNRS. en 1973 et en 1974. Unpublished report. On file, Centre National de la Recherche Scientifique (CNRS), RCP No. 259, Paris.

Goldman, Irving, 1970. Ancient Polynesian Society. Chicago: University of Chicago Press. 
Green, Roger C., 1996. Settlement patterns and complex society in the Windward Society Islands: Retrospective commentary from the 'Opunohu Valley, Mo'orea. In M. Julien, M. Orliac and C. Orliac (eds), Mémoire de Pierre, Mémoire d'Homme: Tradition et Archéologie en Océanie. Paris: Publications de la Sorbonne, pp. 209-28. Green, Roger C. and Christophe Descantes, 1989. Site Records of the 'Opunohu Valley, Mo 'orea. Auckland: The Green Foundation for Polynesian Research.

Green, Roger C., Kaye Green, Roy A. Rappaport, Ann Rappaport and Janet Davidson, 1967. Archeology on the Island of Mo 'orea, French Polynesia. Anthropological Papers of the American Museum of Natural History 51 (2). New York.

Hayden, Brian, 2001. Fabulous feasts: A prolegomenon to the importance of feasting. In Michael Dietler and Brian Hayden (eds), Feasts: Archaeological and Ethnographic Perspectives on Food, Politics, and Power. Washington DC: Smithsonian Institution Press, pp. 23-64.

2014. The Power of Feasts: From Prehistory to the Present. Cambridge: Cambridge University Press.

Henry, Teuira, 1928. Ancient Tahiti. Bernice P. Bishop Museum Bulletin 48. Honolulu.

Horrocks, M., John Peterson and Mike T. Carson, 2015. Pollen, starch, and biosilicate analysis of archaeological deposits on Guam and Saipan, Mariana Islands, Northwest Pacific: Evidence for Chamorro subsistence crops and marine resources. Journal of Island and Coastal Archaeology 10 (1): 97-110.

Junker, Laura L., 1999. Raiding, Trading, and Feasting: The Political Economy of the Philippines. Honolulu: University of Hawaii Press.

Junker, Laura L. and Lisa Niziolek, 2010. Food preparation and feasting in the household and political economy of Pre-Hispanic Philippine chiefdoms. In E.A. Larch (ed.), Inside Ancient Kitchens: New Directions in the Study of Daily Meals and Feasts. Boulder: University Press of Colorado, pp. 17-54.

Kahn, Jennifer G., 1997. Unpublished field notes, Tahuata, Marquesas Islands. 2005. Household and Community Organization in the Late Prehistoric Society Islands (French Polynesia). Unpublished PhD dissertation, Department of Anthropology, University of California, Berkeley.

2007. Power and precedence in ancient house societies: A case study from the Society Island chiefdoms (French Polynesia). In Robin Beck (ed.), The Durable House: House Society Models in Archaeology. Occasional Paper No. 35. Carbondale, Illinois: Center for Archaeological Investigations, Southern Illinois University, pp. 198-223.

2010. A spatio-temporal analysis of 'Oro cult marae in the 'Opunohu Valley, Mo'orea, Society Islands. Archaeology in Oceania 45: 103-10.

2011. Multi-phase construction sequences and aggregate site complexes of the prehistoric Windward Society Islands (French Polynesia). Journal of Island and Coastal Archaeology 6: 24-50.

2013. Temple renovations, aggregate marae, and ritual centers: The ScMo-15 Complex, 'Opunohu Valley, Mo'orea (Society Islands). Rapa Nui Journal 27 (2): 33-49. 


\section{Feasting at Late Prehistoric Sites in the Society Islands}

2014. Colonization, settlement, and process in Central Eastern Polynesia. In Ethan Cochrane and Terry Hunt (eds), Oxford Handbook of Prehistoric Oceania. Oxford Press, pp. 1-11. doi 10.1093/oxfordhb/9780199925070.0

2015. Identifying residences of ritual practitioners in the archaeological record as a proxy for social complexity. Journal of Anthropological Archaeology 40: 59-81.

Kahn, J.G., M. Horrocks and M. Nieuwoudt, 2014. Agriculture, domestic production, and site function: Micro-fossil analyses and late prehistoric landscapes of the Society Islands. Economic Botany 68 (3): 246-63.

Kahn, J. G. and P. V. Kirch, 2013. Residential landscapes and house societies of the late prehistoric Society Islands (French Polynesia). Journal of Pacific Archaeology 4 (1): 50-72.

2014. Monumentality and Ritual Materialization in the Society Islands. Bishop Museum Bulletin in Anthropology 13. Honolulu: Bishop Museum Press.

Kirch, Patrick V. 1991. Chiefship and competitive involution: The Marquesas Islands of Eastern Polynesia. In Timothy Earle (ed.), Chiefdoms: Power, Economy, and Ideology. Cambridge: Cambridge University Press, pp. 119-45.

2001. Polynesian feasting in ethnohistoric, ethnographic, and archaeological contexts: A comparison of three societies. In Michael Dietler and Brian Hayden (eds), Feasts: Archaeological and Ethnographic Perspectives of Food, Politics, and Power. Washington, DC: Smithsonian Institute Press, pp. 168-84.

Kirch, Patrick V. and Roger C. Green 2001. Hawaiki, Ancestral Polynesia: An Essay in Historical Anthropology. Cambridge: Cambridge University Press.

Knudson, Kelly J., Kristin R. Gardella and Jason Yaeger, 2012. Provisioning Inka feasts at Tiwanaku, Bolivia: The geographic origins of camelids in the Pumapunku complex. Journal of Archaeological Science 39 (2): 479-91.

Kolb, Michael J., 1994. Monumentality and the rise of religious authority in precontact Hawai'i. Current Anthropology 35 (5): 521-47.

-1999. Monumental grandeur and political florescence in pre-contact Hawai' $i$ : Excavations at Pi'ilanihale Heiau, Maui. Archaeology in Oceania 37: 71-82. 2006. The origins of monumental architecture in ancient Hawai'i. Current Anthropology 47 (4): 657-65.

Leach, Helen, 2003. Did East Polynesians have a concept of luxury goods? World Archaeology 34 (3): 442-57.

Lepofsky, Dana and Jennifer G. Kahn, 2011. Cultivating an ecological and social balance: Elite demands and commoner knowledge in ancient Ma'ohi agriculture, Society Islands. American Anthropologist 113 (2): 319-35.

Maric, Tamara, 2012. Dynamiques de Peuplement et Transformations Sociopolitiques à Tahiti (Îles de la Société). Unpublished $\mathrm{PhD}$ thesis, Université de Paris I, Panthéon-Sorbonne.

Moerenhout, Jacques-Antoine, 1837. Voyages aux Iles du Grand Océan, Contenant des Documents Nouveaux sur la Géographie Physique et Politique, la Langue, la Littérature, la Religion, les Moeurs, les Usages et les Coutumes de Leurs Habitants; et des Considérations Générales sur Leur Commerce, Leur Histoire et Leur Gouvernement, Dupuis les Temps les Plus Reculés Jusqu'à Nos Jours. 2 volumes. Paris: A. Bertrand. 
Morrison, James 1935. The Journal of James Morrison (Owen Rutter, Ed.). London: Golden Cockerell Press.

Oakes, Nicole R., 1994. The Late Prehistoric Maohi Fare Haupape: An Examination of Household Organization in Mo'orea, French Polynesia. Unpublished MA Thesis, Simon Fraser University, Vancouver, B.C.

Oliver, Douglas L., 1974. Ancient Tahitian Society. Honolulu: University of Hawaii Press.

1989. Oceania: The Native Cultures of Australia and the Pacific Islands. 2 volumes. Honolulu: University of Hawaii Press.

Orliac, Catherine, 1982. Materiaux Pour l'Etude Des Habitations Protohistoriques á Tahiti (Polynésie Française). Unpublished PhD Dissertation, Université de Paris I, Sorbonne.

Ottino-Garanger, P., 2006. Archéologie chez les Taïpi. Papeete: Au Vent des Iles.

Potter, James M., 2000. Pots, parties, and politics: Communal feasting in the American Southwest. American Antiquity 65 (3): 471-92.

Reinhart, Katrinka, 2015. Ritual feasting and empowerment at Yanshi Shangcheng. Journal of Anthropological Archaeology 39: 76-109.

Schachner, Gregson, 2001. Ritual control and transformation in middle-range societies: An example from the American Southwest. Journal of Anthropological Archaeology 20 (2): 168-94.

Sharp, W.D., J.G. Kahn, C.M. Polita and P.V. Kirch, 2010. Rapid evolution of ritual architecture in Central Polynesia indicated by Precise 230Th/U Coral Dating. Proceedings of the National Academy of Science 107 (30): 13234-39.

Suggs, R.C., 1961. The Archaeology of Nuku Hiva, Marquesas Islands, French Polynesia. American Museum of Natural History Anthropological Papers 49. New York.

Thomas, Nicholas, 1990. Marquesan Societies: Inequality and Political Transformation in Eastern Polynesia. Oxford: Clarendon Press.

Wallin, Paul, 2014. Chiefs, fashion and zeitgeist: Exclusion as an expansion strategy in kinship based groups in the Society Islands. Studies in Global Archaeology 20: 297-316.

\section{ABSTRACT}

Much of the research into East Polynesian ceremonial sites focuses on temple-altar (marae-ahu) complexes as sacred sites where varied religious rituals and rites of passage were performed. Yet ethnohistoric documents and the Tahitian lexicon suggest a broader role for Ma'ohi (indigenous Tahitian) ceremonial architecture as the foci of individual and corporate ceremonies of a religious, economic and political nature. Utilising a spatio-temporal perspective, I investigate the function of feasting at terraces attached to a range of community and familial level temples, in addition to communal spaces within residential sites in the Society Islands. My goal is to explore the ways that Ma'ohi household leaders, chiefs and priests may have utilised feasting to materialise their economic authority, while at the same time facilitating the formation of communal identities. I utilise archaeological data to identify feasting 


\section{Feasting at Late Prehistoric Sites in the Society Islands}

at monumental architectural sites of varying scale and complexity and house sites of differing status. I then turn to ethnographic analogy and social theory to suggest differing functions of feasting at different site types. As I argue, feasting serves as a highly visible social act, representing not only a political leader's generosity, but delineating boundaries of particular social groups and control over resources. In the Society Island chiefdoms, at both the household and community scales, feasting is strongly correlated, but not uniquely associated with, ceremonial sites and served varied secular and sacred functions. I conclude that feasting actively solidified local and community level leader's economic, socio-political and ideological power in varied ceremonial contexts of the late prehistoric Society Island chiefdoms.

Keywords: feasting, ceremonial architecture, Society Islands, socio-political strategies, spatio-temporal analyses, communal identity.

\section{CITATION AND AUTHOR CONTACT DETAILS}

Kahn, ${ }^{1}$ Jennifer G., 2016. The functionality of feasting at late prehistoric residential and ceremonial sites in the Society Islands. Journal of the Polynesian Society 125 (3): 203-238. DOI: http//dx.doi.org/10.15286/jps.125.3.203-238

${ }^{1}$ Correspondence: Anthropology Department, College of William and Mary, Washington Hall, Williamsburg, VA 23185, USA. Email: jgkahn01@wm.edu 